\title{
Pteridine-, thymidine-, choline- and imidazole-derived alkaloids from the Australian ascidian, Leptoclinides durus
}

\author{
Kathryn E. Rudolph, ${ }^{a, \uparrow}$ Michelle S. Liberio, ${ }^{b, \dagger}$ Rohan A. Davis, ${ }^{b}$ Anthony R. Carroll,, a,b \\ Received (in XXX, XXX) Xth XXXXXXXXX 20XX, Accepted Xth XXXXXXXXX 20XX \\ ${ }_{5}$ DOI: $10.1039 / \mathbf{b 0 0 0 0 0 0 x}$
}

Four new acylated pteridine alkaloids, duramidines A-D, two new acylated thymidine alkaloids, leptoclinidines $\mathrm{A}$ and $\mathrm{B}$, two new 1-acylglyceryl-3-( $O$-carboxyhydroxymethylcholine) alkaloids, durabetaines A and B, three new 1,3-dimethyl-5-methylsulfanylimidazole alkaloids, leptoclinidamines D$\mathrm{F}$, and the known alkaloids leptoclinidamines $\mathrm{B}$ and $\mathrm{C}$ and 6-bromo- $1 H$-indolo-3-yl-oxoacetic acid 10 methyl ester were isolated from the Australian ascidian Leptoclinides durus. The duramidines are the first pteridine alkaloids, possessing a three carbon side chain esterified at C-1' with a 4-hydroxy-2'methoxycinnamic acid, and are either hydroxylated or sulphated at C-2'. The leptoclinidines are the first $3^{\prime}$-indole-3-carboxylic acid ester derivatives of thymidine to be reported in the literature. The durabetaines are the first glyceryl-3-( $O$-carboxyhydroxymethylcholine) alkaloids to be reported from an

15 animal source and are also the only known derivatives from this class to be acylated with aromatic carboxylic acids. MS and NMR analysis established the structures of the new compounds. All compounds were tested for cytotoxic activity against prostate (LNCaP) and breast (MDA-MB-231) cancer cell lines and antimicrobial activity against Pseudomonus aeruginosa and Staphylococcus aureus. All compounds were inactive in the cytotoxicity and antimicrobial screening.

\section{${ }_{20}$ Introduction}

In a previous paper we reported on the alkaloid chemistry of the colonial ascidian Leptoclinides durus from the Great Barrier Reef, Australia which included three indole derivatives, leptoclinidamines A-C. ${ }^{1}$ At the time of isolating these compounds 25 a number of other minor components were observed in HPLC separations, however insufficient quantities prevented structure identification. A subsequent recollection of $L$. durus from the Swain Reefs region of the Great Barrier Reef has now allowed for the isolation of 14 compounds (11 of which are new (Fig 1. 1-8 and

30 10-12)) from this ascidian. In parallel, 143 crude organic extracts derived from Australian ascidians belonging to the family Didemnidae were investigated using analytical HPLC and $\mathrm{MS}^{2}$ and another specimen of $L$. durus, was shown to contain three of the same novel compounds (3, 4 and 11) along with (-)-

35 leptoclinidamine $\mathrm{C}(\mathbf{9})$. In this paper we report the isolation and structure elucidation of compounds 1-8 and 10-12. These compounds were tested for cytotoxicity against prostate (LNCaP) and breast (MDA-MB-231) cancer cell lines as well as a panel of microbes known to be associated with nosocomial infections.

\section{${ }_{40}$ Results and discussion}

Purification of the crude $\mathrm{MeOH}$ extract from the freeze-dried ground ascidan by HPLC on $\mathrm{C}_{18}$ silica gel eluting with a linear gradient from $\mathrm{H}_{2} \mathrm{O}$ to $\mathrm{MeOH}$ (containing 1\% TFA) yielded many fractions eluting between $30 \%$ and $70 \% \mathrm{MeOH}$ that contained 45 mixtures of compounds that displayed aromatic signals in their ${ }^{1} \mathrm{H}$ NMR spectra. In addition, many of these fractions displayed molecular ions in the $(+)$-LRESIMS characteristic of brominated compounds. Further purification of pooled fractions containing similar ${ }^{1} \mathrm{H}$ NMR spectra and/or MS signals, by gradient $\mathrm{C}_{18}$ HPLC 50 with mixtures of $\mathrm{H}_{2} \mathrm{O}$ and $\mathrm{MeOH}$ afforded compounds 1-14 in low yield. Analysis of NMR and MS indicated that three of these compounds were the known natural products, (-)-leptoclinidamine C (9) and (+)-leptoclinidamine B (13) isolated previously from $L$. durus $^{1}$ and 6-bromo-1H-indolo-3-yl-oxoacetic acid methyl ester 55 (14) that was previously purified from the Korean sponge Spongosorites $\mathrm{sp}^{3}$

NMR analysis of the 11 new compounds highlighted that they represented groups of compounds from four different structure classes that we have named duramidines, leptoclinidines, ${ }_{60}$ durabetaines and leptoclinidamines.

\section{Duramidines}

Duramidine A (1) was obtained as an optically active yellow gum. Analysis of (+)-HRESIMS data at $\mathrm{m} / z 523.1133$ ( $\Delta 0.4 \mathrm{ppm}$ ) allowed a molecular formula, $\mathrm{C}_{21} \mathrm{H}_{22} \mathrm{~N}_{4} \mathrm{O}_{10} \mathrm{~S}$ to be assigned to 1. A 65 fragment ion at $\mathrm{m} / \mathrm{z} 443$ in the (+)-LRESIMS (loss of $80 \mathrm{amu}$ ) suggested that the compound contained a sulfate ester group. 
<smiles>[R20]C(C)[C@H](OC(=O)/C(C)=C/c1[c-]cc(O)c[13cH]1)c1cnc2c(n1)c(=O)n([R1])c(=O)n2C</smiles>

$1 \mathrm{R}_{1}=\mathrm{CH}_{3}, \mathrm{R}_{2}=\mathrm{SO}_{3} \mathrm{H}$

$2 \mathrm{R}_{1}=\mathrm{CH}_{3}, \mathrm{R}_{2}=\mathrm{H}$

$3 \mathrm{R}_{1}=\mathrm{H}, \mathrm{R}_{2}=\mathrm{SO}_{3} \mathrm{H}$

$4 \mathrm{R}_{1}=\mathrm{H}, \mathrm{R}_{2}=\mathrm{H}$

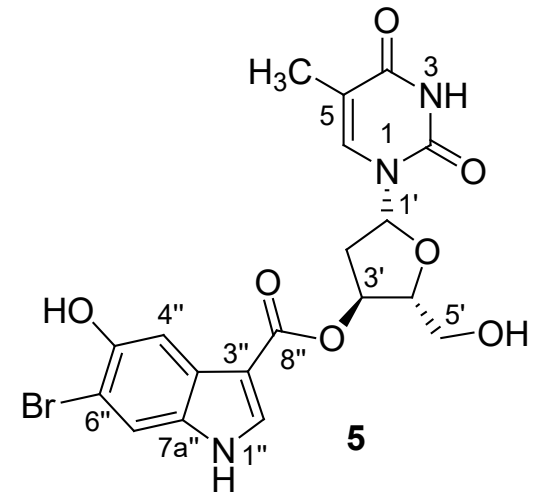<smiles>Cc1cn([C@H]2C[C@H](OC(=O)c3c[nH]c4cc(Br)c(O)cc34)[C@@H](COC(=O)/C(O)=C/c3ccc(O)cc3)O2)c(=O)[nH]c1=O</smiles><smiles></smiles><smiles>[R7]C(=O)C(Cc1c(SC)n(C)c[n+]1C)NC(=O)c1c[nH]c2cc(Br)ccc12</smiles><smiles>[R]Oc1ccc(C(=O)C(=O)N[C@@H](CCC[NH+]=C(N)N)C(=O)O)cc1C(=O)O</smiles><smiles>C[N+](C)(C)CCOC(OCC(O)CO[C@@H](C(=O)O)C(=O)OC(F)(F)F)C1=C[NH2+]c2cc(Br)ccc21</smiles>

13<smiles></smiles>

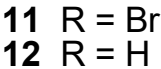<smiles>COC(=O)C(=O)c1c[nH]c2cc(Br)ccc12</smiles>

14

Fig. 1 Alkaloids isolated from Leptoclinides durus

Table $1{ }^{1} \mathrm{H}$ NMR data $(600 \mathrm{MHz})$ for duramidines A-D (1-4) in DMSO- $d_{6}$

\begin{tabular}{lllll} 
Position & $\mathbf{1}$ & $\mathbf{2}$ & $\mathbf{3}$ & $\mathbf{4}$ \\
\hline $1-\mathrm{CH}_{3}$ & $3.54(\mathrm{~s}, 3 \mathrm{H})$ & $3.53(\mathrm{~s}, 3 \mathrm{H})$ & $3.45(\mathrm{~s}, 3 \mathrm{H})$ & $3.46(\mathrm{~s}, 3 \mathrm{H})$ \\
3 & - & - & $11.92(\mathrm{~s}, 1 \mathrm{H})$ & $11.95(\mathrm{~s}, 1 \mathrm{H})$
\end{tabular}




\begin{tabular}{lllll}
\hline $3-\mathrm{CH}_{3}$ & $3.31(\mathrm{~s}, 3 \mathrm{H})$ & $3.30(\mathrm{~s}, 3 \mathrm{H})$ & - & - \\
7 & $8.77(\mathrm{~s}, 1 \mathrm{H})$ & $8.83(\mathrm{~s}, 1 \mathrm{H})$ & $8.74(\mathrm{~s}, 1 \mathrm{H})$ & $8.82(\mathrm{~s}, 1 \mathrm{H})$ \\
$1^{\prime}$ & $5.99(\mathrm{~d}, 3.9,1 \mathrm{H})$ & $5.71(\mathrm{~d}, 5.5,1 \mathrm{H})$ & $5.99(\mathrm{~d}, 3.4,1 \mathrm{H})$ & $5.71(\mathrm{~d}, 6.0,1 \mathrm{H})$ \\
$2^{\prime}$ & $4.71(\mathrm{dq}, 3.9,6.4,1 \mathrm{H})$ & $4.19(\mathrm{dq}, 5.5,6.2,1 \mathrm{H})$ & $4.72(\mathrm{dq}, 3.4,6.1,1 \mathrm{H})$ & $4.20(\mathrm{dq}, 6.0,6.0,1 \mathrm{H})$ \\
$3^{\prime}$ & $1.22(\mathrm{~d}, 6.4,3 \mathrm{H})$ & $1.17(\mathrm{~d}, 6.2,3 \mathrm{H})$ & $1.22(\mathrm{~d}, 6.1,3 \mathrm{H})$ & $1.22(\mathrm{~d}, 6.1,3 \mathrm{H})$ \\
$2^{\prime \prime}-\mathrm{OCH}{ }_{3}$ & $3.72(\mathrm{~s}, 3 \mathrm{H})$ & $3.68(\mathrm{~s}, 3 \mathrm{H})$ & $3.72(\mathrm{~s}, 3 \mathrm{H})$ & $3.69(\mathrm{~s}, 3 \mathrm{H})$ \\
$3^{\prime \prime}$ & $7.12(\mathrm{~s}, 1 \mathrm{H})$ & $7.03(\mathrm{~s}, 1 \mathrm{H})$ & $7.12(\mathrm{~s}, 1 \mathrm{H})$ & $7.12(\mathrm{~s}, 1 \mathrm{H})$ \\
$5^{\prime \prime}, 9^{\prime \prime}$ & $7.66(\mathrm{~d}, 8.4,2 \mathrm{H})$ & $7.65(\mathrm{~d}, 8.4,2 \mathrm{H})$ & $7.67(\mathrm{~d}, 8.4,2 \mathrm{H})$ & $7.67(\mathrm{~d}, 8.4,2 \mathrm{H})$ \\
$6^{\prime \prime}, 8^{\prime \prime}$ & $6.80(\mathrm{~d}, 8.4,2 \mathrm{H})$ & $6.80(\mathrm{~d}, 8.4,2 \mathrm{H})$ & $6.80(\mathrm{~d}, 8.4,2 \mathrm{H})$ & $6.80(\mathrm{~d}, 8.4,2 \mathrm{H})$ \\
$7^{\prime \prime}-\mathrm{OH}$ & $9.87(\mathrm{bs}, 1 \mathrm{H})$ & $9.90(\mathrm{bs}, 1 \mathrm{H})$ & $9.91(\mathrm{bs}, 1 \mathrm{H})$ & $9.96(\mathrm{bs}, 1 \mathrm{H})$ \\
\hline
\end{tabular}

Absorption bands at 3190,1720 and $1700 \mathrm{~cm}^{-1}$ in the IR spectrum were consistent with the molecule containing alcohol, and carbonyl functionality while absorption bands at 285, $320 \mathrm{~nm}$ 5 in the UV spectrum indicated the molecule contained extended conjugated chromophores.

The ${ }^{1} \mathrm{H}$ NMR spectrum of $\mathbf{1}$ (Table 1) contained a methyl doublet at $\delta_{\mathrm{H}} 1.22$, three methyl singlets at $\delta_{\mathrm{H}} 3.31,3.54$ and 3.72, a methine multiplet at $\delta_{\mathrm{H}} 4.71$, a methine doublet at $\delta_{\mathrm{H}} 5.99$ and 10 two $\mathrm{sp}^{2}$ hybridised methine singlets at $\delta_{\mathrm{H}} 7.12$ and 8.77. In addition, two ortho coupled aromatic doublets that each integrated to two protons at $\delta_{\mathrm{H}} 6.80$ and 7.66 and an exchangeable proton at $\delta_{\mathrm{H}} 9.87$ suggested that $\mathbf{1}$ contained an oxygenated paradisubstituted phenyl group. Edited HSQC correlations confirmed 15 the presence of 10 protonated carbon resonances (two of which, $\delta_{C}$ 115.8 and $\delta_{C} 132.3$ represented the four protonated carbons of the oxygenated para-disubstituted phenyl group), indicating that $\mathbf{1}$ contained an additional nine quaternary carbons. The chemical shifts of the carbons attached to the methyl protons at $\delta_{\mathrm{H}} 3.54\left(\delta_{\mathrm{C}}\right.$ $2029.2)$ and $\delta_{\mathrm{H}} 3.31\left(\delta_{\mathrm{C}} 28.5\right)$ indicated that they were substituted by nitrogen atoms, while the carbon attached to the methyl protons resonating at $\delta_{\mathrm{H}} 3.72\left(\delta_{\mathrm{C}} 58.8\right)$ was oxygenated.

A 1,2-dioxygenated propyl group was assigned based upon COSY and HSQC correlations and a 4-hydroxy-2'25 methoxycinnamate group was identified from analysis of HMBC correlations. In particular, correlations were observed from a benzylic olefinic methine singlet at $\delta_{\mathrm{H}} 7.12$ to an oxygenated nonprotonated $\mathrm{sp}^{2}$ carbon at $\delta_{\mathrm{c}} 142.4$, an unsaturated ester carbonyl carbon at $\delta_{\mathrm{C}} 163.4$ and the aromatic protonated carbon resonance 30 at $\delta_{\mathrm{C}} 132.3$ assigned to $\mathrm{C}-5$ " and C-9" of the para-disubstituted phenyl group, while the methoxy proton signal at $\delta_{\mathrm{H}} 3.72$ also correlated to the carbon at $\delta_{\mathrm{C}} 142.4$. The regiochemistry of the double bond was established to be $Z$ based on the observation that the methoxy carbon in $E$ isomers resonates at $56 \mathrm{ppm}$ while in $\mathrm{Z}$ 35 isomers it resonates at $59 \mathrm{ppm} .{ }^{4}$ This regiochemistry was further supported by a strong ROESY correlation between the methoxy protons and the aromatic protons $\mathrm{H}-5^{\prime \prime}$ and $\mathrm{H}-9$ " in duramidine $\mathrm{B}$ (2). A HMBC correlation between $\mathrm{H}-1^{\prime}$ and the ester carbonyl carbon at $\delta_{\mathrm{C}} 163.4$ provided evidence to link the 4-hydroxy-2'40 methoxycinnamate group to $\mathrm{C}-1^{\prime}$ of the propyl group. The chemical shift of $\mathrm{H}-2^{\prime}\left(\delta_{\mathrm{H}} 4.77\right)$ suggested that it was the site of attachment of the sulfate ester group.

The remaining molecular fragment, $\mathrm{C}_{8} \mathrm{H}_{7} \mathrm{~N}_{4} \mathrm{O}_{2}$, represented seven degrees of unsaturation. A coupling of $186 \mathrm{~Hz}$ from the ${ }_{45}$ proton at $\delta_{\mathrm{H}} 8.77$ to the carbon at $\delta_{\mathrm{C}} 146.5$ was consistent with it being a protonated aromatic carbon substituted by a nitrogen atom. ${ }^{5}$ Intense HMBC correlations were observed from this proton to two additional $\mathrm{N}$ substituted aromatic non-protonated carbons at $\delta_{\mathrm{C}} 147.9$ and 147.1 and a weak ${ }^{4} J_{\mathrm{CH}}$ correlation was also observed
${ }_{50}$ to a non-protonated $\mathrm{sp}^{2}$ carbon at $\delta_{\mathrm{C}} 127.0$. The propyl protons $\mathrm{H}$ $1^{\prime}$ and $\mathrm{H}-2^{\prime}$ correlated to the carbon at $\delta_{\mathrm{C}} 147.1$ while $\mathrm{H}-1^{\prime}$ correlated to the protonated heteroaromatic carbon at $\delta_{\mathrm{C}} 146.5$, suggesting that the propyl side chain was attached to a carbon adjacent to C-7. The $N$-methyl protons at $\delta_{\mathrm{H}} 3.54$ also correlated to ${ }_{55}$ the carbon at $\delta_{\mathrm{C}} 147.9 \mathrm{in}$ addition to a carbon at $\delta_{\mathrm{C}} 150.6$, while the remaining $N$-methyl protons at $\delta_{\mathrm{H}} 3.31$ also correlated to the carbon at $\delta_{\mathrm{C}} 150.6$ and the last remaining unassigned quaternary carbon at $\delta_{\mathrm{C}}$ 159.8. These correlations in combination with chemical shift comparisons with literature data were consistent 60 with 1 containing a 1,3-dimethylpteridine moiety substituted at C6 by the propyl side chain. ${ }^{6}$

Table $2{ }^{13} \mathrm{C}$ NMR data (150 MHz) for duramidines A-D (1-4) in DMSO$\underline{d_{6}}$

\begin{tabular}{lllll}
\hline Position & \multicolumn{1}{c}{$\mathbf{1}^{a}$} & \multicolumn{1}{c}{$\mathbf{2}^{a}$} & \multicolumn{1}{c}{$\mathbf{3}^{b}$} & \multicolumn{1}{c}{$\mathbf{4}^{b}$} \\
\hline $1-\mathrm{CH}_{3}$ & $29.2\left(\mathrm{CH}_{3}\right)$ & $29.0\left(\mathrm{CH}_{3}\right)$ & $28.0\left(\mathrm{CH}_{3}\right)$ & $28.2\left(\mathrm{CH}_{3}\right)$ \\
2 & $150.6(\mathrm{C})$ & $150.3(\mathrm{C})$ & $149.6(\mathrm{C})$ & $150.0(\mathrm{C})$ \\
$3-\mathrm{CH}_{3}$ & $28.5\left(\mathrm{CH}_{3}\right)$ & $28.5\left(\mathrm{CH}_{3}\right)$ & - & - \\
4 & $159.8(\mathrm{C})$ & $159.7(\mathrm{C})$ & $160.0(\mathrm{C})$ & $159.8(\mathrm{C})$ \\
$4 a$ & $127.0(\mathrm{C})$ & $126.2(\mathrm{C})$ & $127.5(\mathrm{C})$ & $127.6(\mathrm{C})$ \\
6 & $147.1(\mathrm{C})$ & $147.2(\mathrm{C})$ & $147.0(\mathrm{C})$ & $147.2(\mathrm{C})$ \\
7 & $146.5(\mathrm{CH})$ & $146.8(\mathrm{CH})$ & $146.5(\mathrm{CH})$ & $146.5(\mathrm{CH})$ \\
$8 \mathrm{a}$ & $147.9(\mathrm{C})$ & $147.9(\mathrm{C})$ & $149.8(\mathrm{C})$ & $149.2(\mathrm{C})$ \\
$1^{\prime}$ & $77.0(\mathrm{CH})$ & $78.5(\mathrm{CH})$ & $76.9(\mathrm{CH})$ & $78.5(\mathrm{CH})$ \\
$2^{\prime}$ & $72.7(\mathrm{CH})$ & $67.4(\mathrm{CH})$ & $72.4(\mathrm{CH})$ & $67.3(\mathrm{CH})$ \\
$3^{\prime}$ & $16.2(\mathrm{CH})$ & $19.2(\mathrm{CH})$ & $15.8(\mathrm{CH})$ & $19.1(\mathrm{CH})$ \\
$1^{\prime \prime}$ & $163.4(\mathrm{C})$ & $163.4(\mathrm{C})$ & $163.3(\mathrm{C})$ & $163.2(\mathrm{C})$ \\
$2^{\prime \prime}$ & $142.4(\mathrm{C})$ & $142.2(\mathrm{C})$ & $142.4(\mathrm{C})$ & $142.4(\mathrm{C})$ \\
$2^{\prime \prime}-\mathrm{OCH}$ & $58.8(\mathrm{CH})$ & $58.8(\mathrm{CH})$ & $58.6(\mathrm{CH})$ & $58.7(\mathrm{CH})$ \\
$3^{\prime \prime}$ & $125.0(\mathrm{CH})$ & $124.8(\mathrm{CH})$ & $125.2(\mathrm{CH})$ & $124.7(\mathrm{CH})$ \\
$4^{\prime \prime}$ & $124.0(\mathrm{C})$ & $123.4(\mathrm{C})$ & $124.0(\mathrm{C})$ & $124.0(\mathrm{C})$ \\
$5^{\prime \prime}, 9^{\prime \prime}$ & $132.3(\mathrm{CH})$ & $132.1(\mathrm{CH})$ & $132.1(\mathrm{CH})$ & $132.0(\mathrm{CH})$ \\
$6^{\prime \prime}, 8^{\prime \prime}$ & $115.8(\mathrm{CH})$ & $115.7(\mathrm{CH})$ & $115.7(\mathrm{CH})$ & $115.6(\mathrm{CH})$ \\
$7^{\prime \prime}$ & $159.0(\mathrm{C})$ & $158.8(\mathrm{C})$ & $158.8(\mathrm{C})$ & $158.7(\mathrm{C})$ \\
& & &
\end{tabular}

${ }_{65}{ }^{a}$ Chemical shifts determined from HSQC and HMBC data.

${ }^{b}$ Chemical shifts obtained from a ${ }^{13} \mathrm{C}$ NMR spectrum of a mixture of $\mathbf{3}$ and $\mathbf{4}$ and assigned following analysis of HSQC and HMBC data.

Duramidine A (1) was unstable in DMSO and readily converted to a molecule (2) with a molecular weight 80 amu smaller. (+)70 HRESIMS analysis of its molecular ion at $\mathrm{m} / z 443.1583$ allowed a molecular formula $\mathrm{C}_{21} \mathrm{H}_{22} \mathrm{~N}_{4} \mathrm{O}_{7}$ to be assigned, indicating that 2 was the desulfated derivative of $\mathbf{1}$. The ${ }^{1} \mathrm{H}$ NMR spectrum of this product was identical to that obtained for a second compound, duramidine B (2), isolated by HPLC purification of the crude 75 extract. The most prominent difference in the ${ }^{1} \mathrm{H}$ NMR spectrum 
of 2 compared to that of 1 was the 0.28 and 0.52 ppm upfield shifts of the proton signals assigned to $\mathrm{H}-1^{\prime}$ and $\mathrm{H}-2^{\prime}$, respectively, and this was in full agreement with the molecule lacking a sulfate ester group at C-2'. Full 2D NMR analysis confirmed this assignment.

5 Schmid has analysed chemical shift and coupling constant data for a series of 1-aryl-1,2-disubstituted propanes and concluded that vicinal coupling constants should be used cautiously when assigning either threo or erytho configuration and analysis of a combination of data provides a more useful insight. ${ }^{7}$ There are six ${ }_{10}$ potential staggered conformations (three for erythro $\mathrm{E}_{\mathrm{T}}, \mathrm{E}_{\mathrm{G} 1}, \mathrm{E}_{\mathrm{G} 2}$ and three for threo $\mathrm{T}_{\mathrm{T}}, \mathrm{T}_{\mathrm{G} 1}, \mathrm{~T}_{\mathrm{G} 2}$ isomers) for diasteromeric 1,2disubstituted-1-aryl propanes (Fig. 2).

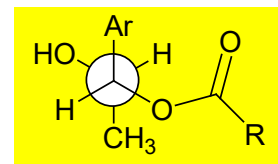

$\mathrm{E}_{\mathrm{T}}$

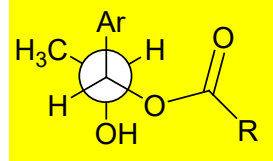

$\mathrm{T}_{\mathrm{T}}$

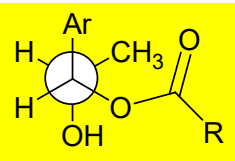

$\mathrm{E}_{\mathrm{G} 1}$

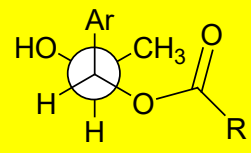

$\mathrm{T}_{\mathrm{G} 1}$

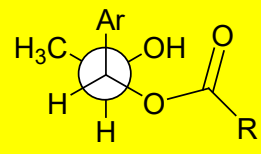

$\mathrm{E}_{\mathrm{G} 2}$

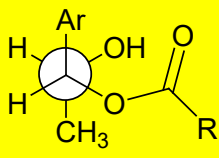

$\mathrm{T}_{\mathrm{G} 2}$
Fig. 2 Conformations of 1,2 disubstituted 1-arylpropanes

15 Four of these conformations have the vicinal protons in a gauche relationship and two in a trans relationship. Since small vicinal coupling constants were observed between $\mathrm{H}-1^{\prime}$ 'and $\mathrm{H}-2^{\prime}$ for $\mathbf{1}$ (3.9 $\mathrm{Hz}$ ) and $2(5.5 \mathrm{~Hz})$ this suggests that $\mathrm{H}-1^{\prime}$ and $\mathrm{H}-2^{\prime}$ occupy a gauche conformation thus ruling out the two trans conformations (ЕT and

${ }_{20} \mathrm{~T}_{\mathrm{T}}$ ). In the ROESY spectrum for $\mathbf{2}$, a strong ROE was observed between the methyl protons $\mathrm{H}_{3}-3^{\prime}$ and $\mathrm{H}_{-1} 1^{\prime}$ indicating that $\mathrm{H}_{3}-3^{\prime}$ and $\mathrm{H}-1^{\prime}$ must also be in a gauche relationship. This observation also rules out the threo $\left(\mathrm{E}_{\mathrm{G} 1}\right)$ and erythro $\left(\mathrm{T}_{\mathrm{G} 1}\right)$ conformations. To distinguish between the two remaining conformations, ROESY 25 correlations observed between $\mathrm{H}-2^{\prime}$ and $\mathrm{H}-7$ were only possible in the threo isomer $\left(\mathrm{T}_{\mathrm{G} 2}\right)$ since there protons occupy gauche positions, while in the erythro isomer $\left(\mathrm{E}_{\mathrm{G} 2}\right)$ these protons are trans to each other and so are too far apart to show ROE correlations. Therefore the dioxygenated propyl side chain in $\mathbf{2}$ (and logically in $\mathbf{1}$ as well) 30 was assigned threo relative configuration. Unfortunately the absolute configuration for $\mathbf{2}$ could not be determined since the compound decomposed before any chemical derivatisation could be attempted.

Duramidine C (3) was isolated as an optically active yellow 35 gum. The molecular formula, $\mathrm{C}_{20} \mathrm{H}_{20} \mathrm{~N}_{4} \mathrm{O}_{10} \mathrm{~S}$ was determined by interpretation of (-)-HRESIMS in conjunction with the NMR data. Analysis of the ${ }^{1} \mathrm{H}$ and ${ }^{13} \mathrm{C}$ NMR (Table 2), together with HSQC and $\mathrm{HMBC}$ data for $\mathbf{3}$, showed that it had very similar chemical shifts and correlations to that obtained for duramidine A (1), the
40 major difference being the replacement of the $N$-methyl signals at $\delta_{\mathrm{H}} 3.31 / \delta_{\mathrm{C}} 28.5$ with an exchangeable proton signal at $\delta_{\mathrm{H}} 11.92$. The (-)-HRESIMS result corroborated that the molecular weight difference was due to loss of one of the methyl groups in $\mathbf{1}$. Since the exchangeable proton at $\delta_{\mathrm{H}} 11.92$ correlated to both $\mathrm{C}-4$ and $\mathrm{C}$ ${ }_{45} 4 \mathrm{a}$ in an HMBC spectrum this indicated that 3 was the $N-3$ demethyl derivative of $\mathbf{1}$. ROESY correlations were identical with those observed for $\mathbf{2}$ suggesting that $\mathbf{3}$ could also be assigned threo relative configuration the propyl side chain. Duramidine $\mathrm{C}$ was unstable and readily hydrolysed to its desulfated derivative 50 duramidine D (4).

Duramidine D (4) was isolated as an optically active yellow gum. The molecular formula, $\mathrm{C}_{20} \mathrm{H}_{20} \mathrm{~N}_{4} \mathrm{O}_{7}$ was determined by interpretation of (-)-HRESIMS in conjunction with the NMR data. This data suggested that $\mathbf{4}$ was the desulfated derviative of $\mathbf{3}$. The 55 major difference in the ${ }^{1} \mathrm{H}$ NMR data for $\mathbf{4}$ compared to $\mathbf{3}$ was the upfield shift of the resonsonces associated with $\mathrm{H}-1$ ' and $\mathrm{H}-2$ ' since these were shifted 0.28 and $0.52 \mathrm{ppm}$ upfield, respectively. These chemical shift differences were completely analogous to those observed between 1 and 2 and therefore duramidine D (4) was 60 deduced to be the 2 '-desulfated derivative of 3 . ROESY correlations were identical with those observed for $\mathbf{2}$ and $\mathbf{3}$ suggesting that $\mathbf{4}$ could also be assigned threo relative configuration the propyl side chain.

6-Propylpteridines have been isolated previously from insect, ${ }^{8}$ ${ }_{65}$ polychaete worm, ${ }^{9}$ sponge, ${ }^{6,10}$ ascidan ${ }^{11,12}$ and coral sources. ${ }^{13}$ however no sulfated pteridines, nor pteridines esterified with aromatic carboxylic acids, have been reported previously.

\section{Leptoclinidines}

Leptoclinidine A (5) was isolated as an optically active yellow 70 gum. The (+)-LRESIMS spectrum for $\mathbf{5}$ had two equally intense peaks at $\mathrm{m} / \mathrm{z} 502$ and 504 suggesting that the molecule contained one bromine atom. Analysis of (+)-HRESIMS data obtained for the sodiated adduct ion at $\mathrm{m} / \mathrm{z} 502.0226$ established a molecular formula $\mathrm{C}_{19} \mathrm{H}_{18} \mathrm{BrN}_{3} \mathrm{O}_{7}$ for $\mathbf{5}$.

75 The ${ }^{1} \mathrm{H}$ NMR spectrum of 5 contained signals for two olefinic/aromatic singlets at $\delta_{\mathrm{H}} 7.57$ and 7.58 , one aromatic doublet at $\delta_{\mathrm{H}} 8.06$, one olefinic quartet at $\delta_{\mathrm{H}} 7.79$, three downfield exchangeable protons at $\delta_{\mathrm{H}} 11.32,11.80$ and 9.81 and one upfield exchangeable proton at $\delta_{\mathrm{H}} 5.22$, five heterosubstituted aliphatic 80 proton muliplets at $\delta_{\mathrm{H}} 6.29,5.43,4.16$ and $3.71(2 \mathrm{H})$, two additional aliphatic multiplets at $\delta_{\mathrm{H}} 2.36$ and 2.40 and one allylic methyl doublet at $\delta_{\mathrm{H}} 1.79$. Edited HSQC correlations established that 5 contained three protonated $\mathrm{sp}^{2}$ carbons at $\delta_{\mathrm{C}} 133.9,116.0$ and 105.7, three heterosubstituted methine carbons at $\delta_{\mathrm{C}} 83.9,73.9$ 85 and 84.8 , one oxygenated methylene carbon at $\delta_{\mathrm{C}} 61.4$, one aliphatic methylene carbon at $\delta_{\mathrm{C}} 37.1$ and one methyl carbon at $\delta_{\mathrm{C}}$ 12.3. A COSY correlation between the exchangeable proton at $\delta_{\mathrm{H}}$ 11.80 to the aromatic proton at $\delta_{\mathrm{H}} 8.06$ was indicative of $\mathrm{H}-1$ " and $\mathrm{H}-2$ " being part of an indole moiety.

90 Table $3{ }^{1} \mathrm{H}(600 \mathrm{MHz})$ and ${ }^{13} \mathrm{C}(150 \mathrm{MHz})$ NMR spectroscopic data for leptoclinidines A and B (5 and 6) in DMSO- $d_{6}$

\begin{tabular}{lllllll}
\hline Position & $\delta_{\mathrm{C}}$ & $\delta_{\mathrm{H}}($ mult, $J$ in Hz, int. $)$ & HMBC & $\delta_{\mathrm{C}}$ & $\delta_{\mathrm{H}}(\mathrm{mult}, J$ in Hz, int. $)$ & HMBC \\
\hline 2 & $150.4(\mathrm{C})$ & - & & $150.4(\mathrm{C})$ & - & - \\
3 & - & $11.32(\mathrm{~s}, 1 \mathrm{H})$ & 4,5 & - & $11.37(\mathrm{~s}, 1 \mathrm{H})$ & - \\
4 & $163.5(\mathrm{C})$ & - & & $163.6(\mathrm{C})$ & - & - \\
5 & $109.6(\mathrm{C})$ & - & & $110.0(\mathrm{C})$ & - & -
\end{tabular}




\begin{tabular}{|c|c|c|c|c|c|c|}
\hline $5-\mathrm{CH}_{3}$ & $12.2\left(\mathrm{CH}_{3}\right)$ & $1.79(\mathrm{~d}, 1.0,3 \mathrm{H})$ & $4,5,6$ & $11.9\left(\mathrm{CH}_{3}\right)$ & $1.72(\mathrm{~d}, 1.0,3 \mathrm{H})$ & $4,5,6$ \\
\hline 6 & $135.9(\mathrm{CH})$ & $7.79(\mathrm{q}, 1.0,1 \mathrm{H})$ & $2,4,5,5-\mathrm{CH}_{3}$ & $136.0(\mathrm{CH})$ & $7.55(\mathrm{q}, 1.0,1 \mathrm{H})$ & $2,4,5,5-\mathrm{CH}_{3}$ \\
\hline $1^{\prime}$ & $83.8(\mathrm{CH})$ & $6.29(\mathrm{dd}, 6.2,8.5,1 \mathrm{H})$ & 2,6 & $84.3(\mathrm{CH})$ & $6.32(\mathrm{dd}, 6.8,7.7,1 \mathrm{H})$ & 2,6 \\
\hline & & $2.40(\mathrm{ddd}, 6.3,8.5,14.4,1 \mathrm{H})$ & $1^{\prime}, 3^{\prime}$ & & $2.57(\mathrm{ddd}, 7.8,7.8,15.1,1 \mathrm{H})$ & $1^{\prime}, 3^{\prime}$ \\
\hline $3^{\prime}$ & $73.8(\mathrm{CH})$ & $5.43(\mathrm{ddd}, 2.1,2.2,6.3,1 \mathrm{H})$ & $1^{\prime}, 4^{\prime}, 5^{\prime}, 1^{\prime \prime}$ & $73.3(\mathrm{CH})$ & $5.54(\mathrm{ddd}, 2.6,2.1,7.8,1 \mathrm{H})$ & $1^{\prime}, 4^{\prime}, 5^{\prime}, 1^{\prime \prime}$ \\
\hline $4^{\prime}$ & $84.7(\mathrm{CH})$ & $4.16(\mathrm{ddd}, 2.2,3.4,3.4,1 \mathrm{H})$ & $3^{\prime}$ & $81.3(\mathrm{CH})$ & $4.44(\mathrm{ddd}, 2.6,4.5,4.5,1 \mathrm{H})$ & $3^{\prime}$ \\
\hline $1^{\prime \prime}$ & - & $11.80(\mathrm{~d}, 3.1,1 \mathrm{H})$ & $2^{\prime \prime}, 3 ", 3 a^{\prime \prime}, 7 a^{\prime \prime}$ & & $11.83(\mathrm{~d}, 2.5,1 \mathrm{H})$ & - \\
\hline $2^{\prime \prime}$ & $133.8(\mathrm{CH})$ & $8.06(\mathrm{~d}, 3.1,1 \mathrm{H})$ & $3 ", 3 a^{\prime \prime}, 7 a^{\prime \prime}, 8^{\prime \prime}$ & $134.0(\mathrm{CH})$ & $8.09(\mathrm{~d}, 2.5,1 \mathrm{H})$ & $3 ", 3 a^{\prime \prime}, 7 a^{\prime \prime}$ \\
\hline $3^{\prime \prime}$ & $105.1(\mathrm{C})$ & - & - & $104.9(\mathrm{C})$ & - & - \\
\hline $3 a^{\prime \prime}$ & $126.3(\mathrm{C})$ & - & - & $126.1(\mathrm{C})$ & - & - \\
\hline $4^{\prime \prime}$ & $105.5(\mathrm{CH})$ & $7.57(\mathrm{~s}, 1 \mathrm{H})$ & 6", 7a" & $105.6(\mathrm{CH})$ & $7.59(\mathrm{~s}, 1 \mathrm{H})$ & $6^{\prime \prime}, 7 \mathrm{a}^{\prime \prime}$ \\
\hline $7 a^{\prime \prime}$ & $131.5(\mathrm{C})$ & - & & $131.0(\mathrm{C})$ & - & - \\
\hline $8^{\prime \prime}$ & $163.6(\mathrm{C})$ & - & & $163.5(\mathrm{C})$ & - & - \\
\hline $1^{\prime \prime \prime}$ & & & & $163.6(\mathrm{C})$ & - & - \\
\hline $2^{\prime \prime \prime}$ & & & & $142.4(\mathrm{C})$ & - & - \\
\hline $2^{\prime \prime \prime-O C H}$ & & & & $58.6\left(\mathrm{CH}_{3}\right)$ & $3.67(\mathrm{~s}, 3 \mathrm{H})$ & $2^{\prime \prime \prime}$ \\
\hline $3^{\prime \prime \prime}$ & & & & $124.4(\mathrm{CH})$ & $6.92(\mathrm{~s}, 1 \mathrm{H})$ & $1^{\prime \prime \prime}, 2^{\prime \prime \prime}, 5^{\prime \prime \prime}, 9^{\prime \prime \prime}$ \\
\hline $4^{\prime \prime \prime}$ & & & & $123.7(\mathrm{C})$ & - & - \\
\hline $5^{\prime \prime \prime}, 9^{\prime \prime \prime}$ & & & & $131.9(\mathrm{CH})$ & $7.57(\mathrm{~d}, 8.4,2 \mathrm{H})$ & $3^{\prime \prime \prime}, 5^{\prime \prime \prime}, 7^{\prime \prime \prime}, 9^{\prime \prime \prime}$ \\
\hline $6^{\prime \prime \prime}, 8^{\prime \prime \prime}$ & & & & $115.6(\mathrm{CH})$ & $6.77(\mathrm{~d}, 8.4,2 \mathrm{H})$ & $4^{\prime \prime \prime}, 6^{\prime \prime \prime}, 8^{\prime \prime \prime}$ \\
\hline $7^{\prime \prime \prime}$ & & & & 158. (C) & - & - \\
\hline 7"'-OH & & & & - & $9.92(\mathrm{~s}, 1 \mathrm{H})$ & $6^{\prime \prime \prime}, 7^{\prime \prime \prime}, 8^{\prime \prime \prime}$ \\
\hline
\end{tabular}

HMBC correlations from $\delta_{\mathrm{H}} 11.80$ to carbons at $\delta_{\mathrm{C}} 133.9,105.5$, 126.3 and 131.2 and from $\delta_{\mathrm{H}} 8.06$ to $\delta_{\mathrm{C}} 105.5,126.3$ and 131.2 further supported the presence of an indole group. The aromatic ${ }_{5}$ singlet at $\delta_{\mathrm{H}} 7.57$ correlated to the carbon at $\delta_{\mathrm{C}} 131.2$ while the aromatic singlet at $\delta_{\mathrm{H}} 7.58$ correlated to the carbon at $\delta_{\mathrm{C}} 126.3$ suggesting that these protons could be assigned to H-4" and H-7" of the indole. These protons further correlated to carbons at $\delta_{\mathrm{C}}$ 149.4 and 106.1 while the phenolic proton at $\delta_{\mathrm{H}} 9.81$ correlated to 10 both $\delta_{\mathrm{C}} 149.4$ and carbons resonating at $\delta_{\mathrm{C}} 105.5$ and 106.1 indicating that $\mathrm{C}-5$ " was substituted by a hydroxy group and C-6" by a bromine atom. An additional HMBC correlation from $\mathrm{H}-2$ " to a carbonyl carbon at $\delta_{C} 164.0$ indicated that the indole was substituted at C-3" by a carboxyl group. COSY and HMBC 15 correlations demonstrated that the seven aliphatic multiplets were part of a 2-deoxypentose moiety. This sugar group was established to be deoxyribose since strong ROESY correlations were observed between $\mathrm{H}-1^{\prime}$ and $\mathrm{H}-4^{\prime}$ and between $\mathrm{H}-3^{\prime}$ and $\mathrm{H}_{2}-5^{\prime}$. The olefinic proton at $\delta_{\mathrm{H}} 7.79$ (attached to a carbon at $\delta_{\mathrm{C}} 136.0$ ) showed a ${ }_{20}$ COSY correlation to the methyl protons at $\delta_{\mathrm{H}} 1.79$ confirming that the methyl was allylic. HMBC correlations from $\delta_{\mathrm{H}} 1.79$ and 7.79 to carbons at $\delta_{\mathrm{C}} 163.9$ and 109.9 , from $\delta_{\mathrm{H}} 7.79$ to carbons at $\delta_{\mathrm{C}}$ 150.7 and 83.9 , from the anomeric proton, $\delta_{\mathrm{H}} 6.29$, to carbons at $\delta_{\mathrm{C}} 136.0$ and 150.7 and from the exchangeable proton at $\delta_{\mathrm{H}} 11.32$ 25 to carbons at $\delta_{\mathrm{C}} 109.9$ and 163.9 were consistent with the presence of a thymidine moiety. Finally, a HMBC correlation from $\mathrm{H}-3^{\prime}$ to the carbonyl carbon at $\delta_{\mathrm{C}} 164.0$ indicated that 5 was a 3 '-indole-3carboxylic acid ester derivative of thymidine. The absolute configuration of the stereogenic centres in $\mathbf{5}$ was determined by 30 comparison of its optical rotation with that reported for a series of (-)-3'-acyl-thymidine derivatives. ${ }^{14}$ In particular the sign and magnitude of the optical rotation for 5 was very similar that reported for ester derivatives with greater than two carbons in the ester chain and was almost identical with the optical rotation 35 reported for (-)-3'-benzoyl-thymidine suggesting that $\mathbf{5}$ contained the natural enantiomer of thymidine.

Leptoclinidine B (6) was isolated as an optically active yellow gum. The molecular ion in the (+)-LRESIMS spectrum for 6 also had two equally intense peaks suggesting that one bromine atom 40 was present. Analysis of (+)-HRESIMS data obtained for a sodiated molecular ion at $m / z 678.0669$ established a molecular formula, $\mathrm{C}_{29} \mathrm{H}_{26} \mathrm{BrN}_{3} \mathrm{O}_{10}$, for $\mathbf{6}$. The ${ }^{1} \mathrm{H}$ NMR spectrum of $\mathbf{6}$ (Table 3 ) contained all of the same signals observed for $\mathbf{5}$ except the exchangeable signal at $\delta_{\mathrm{H}} 5.22$ which was replaced in $\mathbf{6}$ with 45 signals indicative of a 4-hydroxy-2'-methoxycinnamate moiety and in addition the oxygenated methylene protons, $\mathrm{H}_{2}-5^{\prime}$ were shifted $0.79 \mathrm{ppm}$ downfield. Leptoclinidine B was therefore assigned as the 5'-(4-hydroxy-2'-methoxycinnamate) ester of leptoclinidine A. Detailed 2D NMR analysis confirmed this 50 assignment.

The leptoclinidines are the first examples of thymidine derivatives esterified by an indole-3-carboxylic acid to be reported in the literature. Leptoclinidine $B$ is also the first example of a 4hydroxy-2'-methoxycinnamic acid ester of thymidine.

55

\section{Durabetaines}

Durabetaine A (7) was isolated as a colourless gum. A prominent molecular ion at $\mathrm{m} / \mathrm{z} 428.1918$ in the $(+)$ HRESIMS allowed a 60 molecular formula of $\mathrm{C}_{20} \mathrm{H}_{30} \mathrm{NO}_{9}{ }^{+}$to be assigned to 7. Analysis of ${ }^{1} \mathrm{H}$ NMR data for 7 identified signals indicative of a 4-hydroxy-2'- 
methoxycinnamate, in addition to ten heteroatom substituted methine and methylene protons between $\delta_{\mathrm{H}} 5.07$ and 3.60, and a nine proton singlet at $\delta_{\mathrm{H}} 3.11$. Edited HSQC correlations identified four methylene carbons between $\delta_{\mathrm{C}} 60.4$ and 68.3 , an oxygenated 5 methine carbon at $\delta_{\mathrm{C}} 67.3$, a dioxygenated methine carbon at $\delta_{\mathrm{C}}$ 97.4 and a methyl carbon signal at $\delta_{C} 53.1$ that could be assigned to three equivalent methyl groups attached to a quaternary nitrogen atom. A glycerol group was assigned from COSY correlations between the methylene protons at $\delta_{H} 4.12,4.20$ and $3.63(2 \mathrm{H})$ and 10 a methine proton at $\delta_{\mathrm{H}} 3.96$, while an ethyl group was assigned from COSY correlations between methylene protons at $\delta_{\mathrm{H}} 3.97$, 4.04 and $3.60(2 \mathrm{H})$. The presence of a choline group was deduced from HMBC correlations between the trimethyl signal at $\delta_{\mathrm{H}} 3.11$ and the methylene carbon at $\delta_{\mathrm{C}} 64.4$ and the methyl carbon at $\delta_{\mathrm{C}}$ 1553.1 and from the methylene proton signal at $\delta_{\mathrm{H}} 3.60$ to the methyl carbon at $\delta_{\mathrm{C}}$ 53.1. HMBC correlations from the dioxygenated methine proton at $\delta_{\mathrm{H}} 5.07$ to oxygenated methylene carbons of the glycerol $\left(\delta_{\mathrm{C}} 68.3\right)$ and choline $\left(\delta_{\mathrm{C}} 60.4\right)$ as well as to a carboxylic acid carbon at $\delta_{\mathrm{C}} 168.4$ showed that a 2,2-dioxyacetic acid moiety
20 formed an acetal linkage to both the choline and glycerol. HMBC correlations from the methylene protons, $\mathrm{H}-1 \mathrm{a}$ and $\mathrm{H}-\mathrm{lb}$, to the carbonyl carbon of the 4-hydroxy-2'-methoxycinnamate indicated that the glycerol was esterified at $\mathrm{C}-1$ by the cinnamate group. The structure of durabetaine A was therefore assigned as 1-(4-hydroxy${ }_{25}$ 2'-methoxycinnamoyl)-glyceryl-3- $(O$ -

carboxyhydroxymethylcholine) (7).

The structure of durabetaine B (8) was similar to that of durabetaine $\mathrm{A}$ except that $\mathbf{8}$ contained a different ester group. A molecular formula $\mathrm{C}_{19} \mathrm{H}_{26} \mathrm{BrN}_{2} \mathrm{O}_{7}{ }^{+}$was deduced from (+)30 HRESIMS analysis. The region of the ${ }^{1} \mathrm{H}$ NMR spectrum upfield of $\delta_{\mathrm{H}} 5.10$ in $\mathbf{8}$ (Table 4) was almost identical to that of 7 however the signals associated with the 4-hydroxy-2'-methoxycinnamate were missing from the spectrum of $\mathbf{8}$ and replaced with signals that were almost identical to those observed for the indole moiety in 35 leptoclinidamine $\mathrm{C}(\mathbf{9})$. This suggested that durabetaine B was 1(6-bromoindole-3-carboxy)-glyeryl-3-( $O$ carboxyhydroxymethylcholine) (8).

Table $4{ }^{1} \mathrm{H}(600 \mathrm{MHz})$ and ${ }^{13} \mathrm{C}(150 \mathrm{MHz})$ NMR data for durabetaines A and B (7 and 8) in DMSO- $d_{6}$

\begin{tabular}{|c|c|c|c|c|c|c|}
\hline Position & $\delta_{\mathrm{C}}^{\mathrm{a}}$ & ${ }^{1} \delta_{\mathrm{H}}$ (mult, $J$ in Hz, int.) & HMBC & $\delta_{\mathrm{C}^{\mathrm{a}}}^{\mathrm{a}}$ & $\delta_{\mathrm{H}}$ (mult, $J$ in $\mathrm{Hz}$, int.) & $\mathrm{HMBC}$ \\
\hline \multirow[t]{2}{*}{1} & $66.1\left(\mathrm{CH}_{2}\right)$ & $4.12(\mathrm{dd}, 6.0,11.1,1 \mathrm{H})$ & $2,3,1^{\prime}$ & $64.9\left(\mathrm{CH}_{2}\right)$ & $4.19(\mathrm{dd}, 5.8,11.2,1 \mathrm{H})$ & $2,3,1^{\prime}$ \\
\hline & & $4.20(\mathrm{dd}, 4.3,11.1,1 \mathrm{H})$ & $2,3,1^{\prime}$ & & $4.25(\mathrm{dd}, 4.4,11.2,1 \mathrm{H})$ & $2,3,1^{\prime}$ \\
\hline 3 & $68.3\left(\mathrm{CH}_{2}\right)$ & $3.63(\mathrm{~m}, 2 \mathrm{H})$ & 1,5 & $68.7\left(\mathrm{CH}_{2}\right)$ & $3.67(\mathrm{~m}, 2 \mathrm{H})$ & $1,2,5$ \\
\hline 5 & $97.4(\mathrm{CH})$ & $5.07(\mathrm{~s}, 1 \mathrm{H})$ & $3,7,9$ & $97.6(\mathrm{CH})$ & $5.06(\mathrm{~s}, 1 \mathrm{H})$ & $3,7,9$ \\
\hline 8 & $64.4\left(\mathrm{CH}_{2}\right)$ & $3.60(\mathrm{~m}, 2 \mathrm{H})$ & $7,8-\mathrm{N}\left(\mathrm{CH}_{3}\right)_{3}$ & $64.6\left(\mathrm{CH}_{2}\right)$ & $3.57(\mathrm{~m}, 2 \mathrm{H})$ & $7,8-\mathrm{N}\left(\mathrm{CH}_{3}\right)_{3}$ \\
\hline $8-\mathrm{N}\left(\mathrm{CH}_{3}\right)_{3}^{+}$ & $53.1\left(3 \mathrm{x} \mathrm{CH}_{3}\right)$ & $3.11(\mathrm{~s}, 9 \mathrm{H})$ & $8,8-\mathrm{N}\left(\mathrm{CH}_{3}\right)_{3}$ & $53.4\left(3 \mathrm{x} \mathrm{CH}_{3}\right)$ & $3.09(\mathrm{~s}, 9 \mathrm{H})$ & $8,8-\mathrm{N}\left(\mathrm{CH}_{3}\right)_{3}$ \\
\hline 9 & $168.4(\mathrm{C})$ & - & - & $168.7(\mathrm{C})$ & - & - \\
\hline $1^{\prime}$ & $163.9(\mathrm{C})$ & - & - & - & $11.99(\mathrm{bs}, 1 \mathrm{H})$ & $3^{\prime}, 3 \mathrm{a}^{\prime}$ \\
\hline $2^{\prime}$ & $142.7(\mathrm{C})$ & - & - & $133.9(\mathrm{CH})$ & $8.12(\mathrm{~d}, 2.6,1 \mathrm{H})$ & $3^{\prime}, 3 a^{\prime}, 7 a^{\prime}, 8^{\prime}$ \\
\hline $2^{\prime}-\mathrm{OCH}_{3}$ & $58.7\left(\mathrm{CH}_{3}\right)$ & $3.67(\mathrm{~s}, 3 \mathrm{H})$ & $\mathrm{C}-2^{\prime}$ & - & - & - \\
\hline $5^{\prime}$ & $132.0(\mathrm{CH})$ & $7.62(\mathrm{~d}, 8.4,1 \mathrm{H})$ & $3^{\prime}, 7^{\prime}, 9^{\prime}$ & $124.5(\mathrm{CH})$ & $7.32(\mathrm{dd}, 1.3,8.5,1 \mathrm{H})$ & $3 a^{\prime}, 7^{\prime}$ \\
\hline $6^{\prime}$ & $115.7(\mathrm{CH})$ & $6.80(\mathrm{~d}, 8.4,1 \mathrm{H})$ & $4^{\prime}, 8^{\prime}$ & $115.6(\mathrm{C})$ & - & - \\
\hline $7^{\prime}$ & $158.8(\mathrm{C})$ & - & - & $115.3(\mathrm{CH})$ & $7.69(\mathrm{~d}, 1.3,1 \mathrm{H})$ & $3 a^{\prime}, 5^{\prime}$ \\
\hline $7 a^{\prime}$ & - & - & - & $137.9(\mathrm{C})$ & - & \\
\hline $8^{\prime}$ & $115.7(\mathrm{CH})$ & $6.80(\mathrm{~d}, 8.4,1 \mathrm{H})$ & $4^{\prime}, 6^{\prime}$ & $164.3(\mathrm{C})$ & - & \\
\hline $9^{\prime}$ & $132.0(\mathrm{CH})$ & $7.62(\mathrm{~d}, 8.4,1 \mathrm{H})$ & $3^{\prime}, 5^{\prime}, 7^{\prime}$ & - & - & \\
\hline
\end{tabular}

Detailed 2D NMR analysis confirmed this structure assignment. The flexible nature of the glyeryl-3-Ocarboxyhydroxymethylcholine moiety precluded assignment of the relative configuration of the two stereogenic centres, C-2 and ${ }_{45} \mathrm{C}-5$ in both 7 and 8 by NMR analysis. Unfortunately 7 and $\mathbf{8}$ were both isolated in very low yield which restricted our ability to derivatise or degrade the compounds. It should be noted that even if sufficient quantity were available, hydrolysis of either $\mathbf{7}$ or $\mathbf{8}$ would yield the achiral products, glycerol and 2-oxo-acetic acid 50 and Mosher ester analysis would only assign the chirality at C-2 without providing evidence to assign the chirality at $\mathrm{C}-5$. The configuration at $\mathrm{C}-2$ and $\mathrm{C}-5$ remains unresolved for both compounds.

Durabetaines A and B are related to lipid esters that have 55 previously been isolated from algae. ${ }^{15-17}$ The significant difference between these algal products and the durabetaines is the replacement of the long chain fatty acid attached at $\mathrm{C}-1$ by aromatic esters. Furthermore the algal derivatives reported to date have all contained a second long chain fatty acid attached at C-2. ${ }_{60}$ Significantly, the durabetaines are the first compound from this structure class to be isolated from an animal source.

\section{Leptoclinidamines}


Leptoclinidamine D (10) was isolated as a colourless gum. (+)HRESIMS analysis of the molecular ion at $\mathrm{m} / \mathrm{z} 465.0571$ in combination with NMR analysis indicated that $\mathbf{1 0}$ was a quaternary amine salt with a formula $\mathrm{C}_{19} \mathrm{H}_{22} \mathrm{BrN}_{4} \mathrm{O}_{3} \mathrm{~S}^{+}$for the cation and with 5 trifluoroacetate as the counter ion. The ${ }^{1} \mathrm{H}$ NMR spectrum of $\mathbf{1 0}$ (Table 5) was almost identical to that reported previously for leptoclinidamine $\mathrm{C}(\mathbf{9}),{ }^{1}$ the only difference being an additional methyl resonance at $\delta_{\mathrm{H}} 3.68$. These protons correlated to a carbon at $\delta_{\mathrm{C}} 52.4$ in the HSQC spectrum and a carbon at $\delta_{\mathrm{C}} 171.4$ in the ${ }_{10} \mathrm{HMBC}$ spectrum and this supported the assignment of $\mathbf{1 0}$ as the methyl ester of 9. Full 2D NMR analysis confirmed this assignment.

NMR analysis of the remaining two new compounds (11 and 12) indicated that each contained a 1,3-dimethyl-5-methyl15 sulfanylimidazole moiety similar to that found in $\mathbf{9}$ and $\mathbf{1 0}$, but differences were clearly evident in the downfield region of their spectra compared to 9 and $\mathbf{1 0}$. Leptoclinidamine E (11) was isolated as its TFA salt and was a pale yellow gum. The $(+)-$ LRESIMS of 11 showed three ions at $m / z$ 462, 464, 466 (1:2:1) 20 which indicated that the molecule contained two bromine atoms. The molecular formula, $\mathrm{C}_{15} \mathrm{H}_{18} \mathrm{Br}_{2} \mathrm{~N}_{3} \mathrm{O}_{2} \mathrm{~S}^{+}$was determined from analysis of (+)-HRESIMS data.

${ }^{1} \mathrm{H}$ NMR data for 11 (Table 6) pointed to the presence of two mutually coupled methylene groups, an amide triplet, an aromatic 25 singlet that integrated to two protons, suggestive of a symmetrical 1,2,3,5-tetrasubstituted phenyl group, in addition to signals for a 1,3-dimethyl-5-methylsulfanylimidazole group. COSY, HSQC and $\mathrm{HMBC}$ correlations confirmed the presence of a substituted histamine in $\mathbf{1 1}$ since correlations from the methylene protons at ${ }_{30} \delta_{\mathrm{H}} 3.02$ of an ethylamido group were observed to C-11 and C-12 of the imidazole moiety. Strong HMBC correlations from the aromatic resonance at $\delta_{\mathrm{H}} 7.96$ to downfield carbons at $\delta_{\mathrm{C}} 163.7$, 153.5 and 131.2 suggested 11 contained a para-hydroxy benzoyl moiety. An additional correlation from these protons to a carbon

35 resonance at $\delta_{\mathrm{C}} 111.7$ supported the positioning of the two bromine atoms at C-2 and C- 6 of the benzoyl system on the basis of the diagnostic carbon chemical shift at $\delta_{\mathrm{C}} 111.7$ being similar to that reported for the previously isolated compounds, cadiolides $\mathrm{A}$ and B. ${ }^{18} \mathrm{HMBC}$ cross-peaks observed from both the methylene protons 40 at $\delta_{\mathrm{H}} 3.48$ and the amide proton at $\delta_{\mathrm{H}} 8.69$ to the benzoyl carbon at $\delta_{\mathrm{C}} 163.7$ (C-7) indicated that an amide bond linked the benzoyl group to the histamine moiety. Leptoclinidamine $\mathrm{E}$ was therefore assigned structure 11.

Table $5{ }^{1} \mathrm{H}(600 \mathrm{MHz})$ and ${ }^{13} \mathrm{C}(150 \mathrm{MHz}) \mathrm{NMR}$ data for 45 leptoclinidamine D (10) in DMSO- $d_{6}$

\begin{tabular}{llll}
\hline Position & $\delta_{\mathrm{C}}{ }^{\mathrm{a}}$ & $\delta_{\mathrm{H}}($ mult,$J$ in $\mathrm{Hz}$, int. $)$ & HMBC \\
\hline 1 & - & $11.72(\mathrm{~d}, 2.8,1 \mathrm{H})$ & $2,3,3 \mathrm{a}, 7 \mathrm{a}$ \\
2 & $129.2(\mathrm{CH})$ & $8.03(\mathrm{~d}, 2.8,1 \mathrm{H})$ & $3,3 \mathrm{a}, 7 \mathrm{a}$ \\
3 & $109.8(\mathrm{C})$ & - & - \\
$3 \mathrm{a}$ & $125.2(\mathrm{C})$ & & - \\
4 & $122.5(\mathrm{CH})$ & $7.94(\mathrm{~d}, 8.4,1 \mathrm{H})$ & $6,7 \mathrm{a}$ \\
5 & $123.6(\mathrm{CH})$ & $7.22(\mathrm{dd}, 1.8,8.4,1 \mathrm{H})$ & $3 \mathrm{a}, 7$ \\
6 & $115.1(\mathrm{C})$ & - & - \\
7 & $114.7(\mathrm{CH})$ & $7.63(\mathrm{~d}, 1.8,1 \mathrm{H})$ & $3 \mathrm{a}, 5$ \\
$7 \mathrm{a}$ & $137.2(\mathrm{C})$ & - & - \\
8 & $164.5(\mathrm{C})$ & - & - \\
$9-\mathrm{NH}$ & - & $8.50(\mathrm{~d}, 9.1,1 \mathrm{H})$ & 8 \\
10 & $50.0(\mathrm{CH})$ & $4.91(\mathrm{dt}, 5.6,9.1,1 \mathrm{H})$ & $8,11,12,17$
\end{tabular}

$\begin{array}{llll}11 & 25.6\left(\mathrm{CH}_{2}\right) & 3.29(\mathrm{~m}, 1 \mathrm{H}) & 10,12,13,17 \\ & & 3.43(\mathrm{dd}, 5.5,15.2,1 \mathrm{H}) & 10,12,13,17 \\ 12 & 136.3(\mathrm{C}) & - & - \\ 13 & 126.3(\mathrm{C}) & - & - \\ 13-\mathrm{SCH}_{3} & 18.6\left(\mathrm{CH}_{3}\right) & 2.29(\mathrm{~s}, 3 \mathrm{H}) & 13 \\ 14-\mathrm{CH}_{3} & 32.6\left(\mathrm{CH}_{3}\right) & 3.77(\mathrm{~s}, 3 \mathrm{H}) & 13,15 \\ 15 & 138.5(\mathrm{CH}) & 9.16(\mathrm{~s}, 1 \mathrm{H}) & 12,13 \\ 16-\mathrm{CH}_{3} & 34.3\left(\mathrm{CH}_{3}\right) & 3.87(\mathrm{~s}, 3 \mathrm{H}) & 12,15 \\ 17 & 171.4(\mathrm{C}) & - & - \\ 17-\mathrm{OCH}_{3} & 52.4\left(\mathrm{CH}_{3}\right) & 3.68(\mathrm{~s}, 3 \mathrm{H}) & 17\end{array}$

${ }^{a}$ Chemical shifts determined from HSQC and HMBC data.

Leptoclinidamine F (12), isolated as a TFA salt, displayed two peaks of equal intensity at $m / z 384$ and 386 in the (+)-LRESIMS suggesting that it was the debromo derivative of 11. (+)-HRESIMS

50 analysis of the molecular ion peak at $\mathrm{m} / \mathrm{z} 384.0393$ established a molecular formula of $\mathrm{C}_{15} \mathrm{H}_{19} \mathrm{BrN}_{3} \mathrm{O}_{2} \mathrm{~S}^{+}$for $\mathbf{1 2}$. The $1 \mathrm{D}$ and $2 \mathrm{D}$ NMR data obtained for $\mathbf{1 2}$ (Table 6) was consistent with it being the 6-debromo derivative of $\mathbf{1 1}$ since the only differences were associated with the replacement of the two proton aromatic singlet 55 with three aromatic protons with splitting patterns and coupling constants consistent with a 1,2,4-trisubstituted phenyl group. 
Table $6{ }^{1} \mathrm{H}(600 \mathrm{MHz})$ and ${ }^{13} \mathrm{C}(150 \mathrm{MHz})$ NMR data for leptoclinidamines E and F (11 and 12) in DMSO- $d_{6}$

\begin{tabular}{|c|c|c|c|c|c|c|}
\hline Position & $\delta_{\mathrm{C}}^{\mathrm{a}}$ & $\delta_{\mathrm{H}}$ (mult, $J$ in $\mathrm{Hz}$, int.) & HMBC & $\delta_{\mathrm{C}}^{\mathrm{a}}$ & $\delta_{\mathrm{H}}($ mult, $J$ in $\mathrm{Hz}$, int.) & HMBC \\
\hline 1 & $153.5(\mathrm{C})$ & - & - & $157.5(\mathrm{C})$ & - & - \\
\hline $1-\mathrm{OH}$ & - & 10.66 (br s, $1 \mathrm{H})$ & - & & $\mathrm{NO}^{\mathrm{b}}$ & - \\
\hline 2 & $111.7(\mathrm{C})$ & - & - & $109.1(\mathrm{C})$ & - & - \\
\hline 3 & $131.2(\mathrm{CH})$ & $7.96(\mathrm{~s}, 2 \mathrm{H})$ & $1,2,4,5,7$ & $132.0(\mathrm{CH})$ & $7.92(\mathrm{~d}, 2.0,1 \mathrm{H})$ & $1,5,7$ \\
\hline 4 & $131.4(\mathrm{C})$ & - & - & $126.7(\mathrm{C})$ & - & - \\
\hline 5 & $131.2(\mathrm{CH})$ & $7.96(\mathrm{~s}, 2 \mathrm{H})$ & $1,3,4,6,7$ & $128.3(\mathrm{CH})$ & $7.63(\mathrm{dd}, 2.0,8.5,1 \mathrm{H})$ & $1,3,7$ \\
\hline 6 & $111.7(\mathrm{C})$ & - & - & $115.9(\mathrm{CH})$ & $6.96(\mathrm{~d}, 8.5,1 \mathrm{H})$ & 2,4 \\
\hline 7 & $163.7(\mathrm{C})$ & - & - & $163.7(\mathrm{C})$ & - & - \\
\hline 8-NH & - & $8.69(\mathrm{t}, 6.0,1 \mathrm{H})$ & 7 & - & $8.52(\mathrm{t}, 6.0,1 \mathrm{H})$ & 7 \\
\hline 9 & $37.2\left(\mathrm{CH}_{2}\right)$ & $3.48(\mathrm{dt}, 6.0,6.6,2 \mathrm{H})$ & 7,11 & $37.1\left(\mathrm{CH}_{2}\right)$ & $3.47(\mathrm{dt}, 6.0,6.9,2 \mathrm{H})$ & 7,11 \\
\hline 10 & $26.6\left(\mathrm{CH}_{2}\right)$ & $3.02(\mathrm{t}, 6.6,2 \mathrm{H})$ & $9,11,12$ & $23.9\left(\mathrm{CH}_{2}\right)$ & $3.01(\mathrm{t}, 6.9,2 \mathrm{H})$ & $9,11,12$ \\
\hline 11 & $137.3(\mathrm{C})$ & - & - & $137.9(\mathrm{C})$ & - & - \\
\hline 12 & $125.7(\mathrm{C})$ & - & - & $125.9(\mathrm{C})$ & - & - \\
\hline $12-\mathrm{SCH}_{3}$ & $18.7\left(\mathrm{CH}_{3}\right)$ & $2.28(\mathrm{~s}, 3 \mathrm{H})$ & 12 & $18.9\left(\mathrm{CH}_{3}\right)$ & $2.27(\mathrm{~s}, 3 \mathrm{H})$ & 12 \\
\hline $13-\mathrm{CH}_{3}$ & $33.8\left(\mathrm{CH}_{3}\right)$ & $3.81(\mathrm{~s}, 3 \mathrm{H})$ & 12,14 & $33.5\left(\mathrm{CH}_{3}\right)$ & $3.80(\mathrm{~s}, 3 \mathrm{H})$ & 12,14 \\
\hline 14 & $138.2(\mathrm{C})$ & $9.19(\mathrm{~s}, 1 \mathrm{H})$ & $11,12,13-\mathrm{CH}_{3}, 15-\mathrm{CH}_{3}$ & $138.5(\mathrm{C})$ & $9.17(\mathrm{~s}, 1 \mathrm{H})$ & 11,12 \\
\hline $15-\mathrm{CH}_{3}$ & $33.3\left(\mathrm{CH}_{3}\right)$ & $3.85(\mathrm{~s}, 3 \mathrm{H})$ & 11,14 & $34.0\left(\mathrm{CH}_{3}\right)$ & $3.84(\mathrm{~s}, 3 \mathrm{H})$ & 14,15 \\
\hline
\end{tabular}

aChemical shifts determined from HSQC and HMBC data

bNot Observed

The duramidines (1-4), leptoclinidines $(\mathbf{5}, \mathbf{6})$, durabetaines $(\mathbf{7}$, 5 8) and leptoclinidamines (9-13) and compound 14 have been screened against the breast cancer cell line MDA-MB-231 and the prostate cancer cell line LNCaP, but showed no cytotoxicity at 10 $\mu \mathrm{M}$ after 72 hours. The compounds (1-14) have also been screened against the bacteria Pseudomonus aeruginosa and Staphylococcus 10 aureus at concentrations up $330 \mu \mathrm{M}$ but showed no antimicrobial activity after 18 hours.

\section{Conclusions}

In summary, 14 alkaloids have been isolated from the Australian ascidian L. durus. Four of the alkaloids, duramidines A-D (1-4) are 15 first examples of propylpteridine alkaloids substituted by either a 4-hydroxy-2'-methoxycinnamate and/or sulfate esters. Leptoclinidines A and B $(\mathbf{5}, \mathbf{6})$ are the first 3 '-indole-3-carboxylic acid ester derivatives of thymidine. Durabetaine $\mathrm{A}$ and $\mathrm{B}(\mathbf{7}, \mathbf{8})$ are the first glyceryl-3-(O-carboxyhydroxymethylcholine) alkaloids to 20 be reported from an animal source and are also the only known derivatives from this class to be acylated with aromatic carboxylic acids. The new leptoclinidamines (11-12) are benzamide derivatives of histamine in which the imidazole is substituted by 5methylsulfanyl and 1,3-dimethyl groups.

\section{${ }_{25}$ Experimental}

\section{General procedures}

NMR spectra were recorded at $30^{\circ} \mathrm{C}$ on a Varian $600 \mathrm{MHz}$ spectrometer equipped with a triple resonance cold probe. The ${ }^{1} \mathrm{H}$ and ${ }^{13} \mathrm{C}$ chemical shifts were referenced to the solvent peak for ${ }_{30} \mathrm{DMSO}-d_{6}$ at $\delta_{\mathrm{H}} 2.49$ and $\delta_{\mathrm{C}} 39.5$. LRESIMS and some HRESIMS were recorded on a Applied Biosystems Mariner Biospectrometry TOF workstation using positive electrospray ionization, mobile phase 1:1 MeOH:H $\mathrm{H}_{2} \mathrm{O}$. HRESIMS were recorded on a Bruker Daltronics Apex III 4.7e Fourier-transform mass spectrometer. IR 35 and UV spectra were recorded on a Bruker Tensor 27 spectrometer and a Shimadzu UV-1800 UV spectrophotometer, respectively. Optical rotations were measured on a JASCO P-1020 polarimeter and $[\alpha]_{\mathrm{D}}$ values are given in $10^{-1} \mathrm{deg} \mathrm{cm}^{2} \mathrm{~g}^{-1}$. Alltech Davisil 30$40 \mu \mathrm{m} 60 \AA \mathrm{C}_{18}$ bonded silica was used to adsorb the ascidian 40 extract prior to HPLC separation. A Merck Hitachi L7100 pump equipped with a Merck Hitachi L7455 PDA detector and a Merck Hitachi L7250 autosampler or a Waters 600 pump equipped with a Waters 996 PDA detector and a Waters 717 autosampler were used for HPLC. A Betasil $\mathrm{C}_{18} 5 \mu \mathrm{m} 143 \AA$ column $(21.2 \mathrm{~mm} \times 150$ $45 \mathrm{~mm})$ and a Phenomenex Luna $\mathrm{C}_{18} 5 \mu \mathrm{m} 100 \AA$ column $(21.2 \times 250$ $\mathrm{mm})$ were used for semi-preparative HPLC separations. All solvents used for chromatography, UV, and MS were Lab-Scan HPLC grade, and the $\mathrm{H}_{2} \mathrm{O}$ was Millipore Milli-Q PF filtered.

\section{Collection and identification of the Ascidian}

50 The ascidian Leptoclinides durus, Kott, 2001 (Didemnidae) was collected by SCUBA diving from the Swain Reefs region of the southern Great Barrier Reef in 2005. A voucher specimen, G325084, has been deposited at the Queensland Museum, South Brisbane, Queensland, Australia. A second sample of L. durus was 55 collected by SCUBA diving at a depth of $23 \mathrm{~m}$ between Surprise and Swain Reefs in Queensland, Australia, during February 2001. A voucher sample G317469 has also been deposited at the Queensland Museum.

\section{${ }_{60}$ Extraction and isolation}

Ascidian Sample 1 (G325084): The freeze-dried and ground ascidian sample (144.9 g) was extracted exhaustively with $\mathrm{MeOH}$ $(5 \times 300 \mathrm{~mL})$ to yield a dark brown residue $(7.6 \mathrm{~g})$. This extract 65 was dissolved in a small amount of $\mathrm{MeOH}(20 \mathrm{~mL})$ and $\mathrm{C}_{18}$ silica gel $(8 \mathrm{~g})$ was added. The solvent was evaporated and the extract, adsorbed on to the gel, was transferred to four refillable HPLC columns $(30 \mathrm{~mm} \times 10 \mathrm{~mm})$. These columns were connected in series to a $\mathrm{C}_{18}$ HPLC column and combined columns eluted with a 70 linear gradient of $\mathrm{H}_{2} \mathrm{O}$ containing $1 \%$ TFA to $\mathrm{MeOH}$ containing 


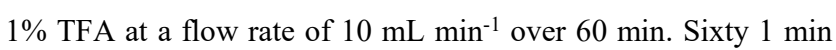
fractions were collected and all fractions were analyzed by $(+)-$ LRESIMS. Fractions containing similar ions were further analysed by ${ }^{1} \mathrm{H}$ NMR spectroscopy and fractions containing similar signals 5 were combined. Fractions 31-37 were combined and further separated by $\mathrm{C}_{18}$ HPLC with a gradient from $80 \% \mathrm{H}_{2} \mathrm{O}$ containing $1 \%$ TFA / $20 \% \mathrm{MeOH}$ containing $1 \%$ TFA to $20 \% \mathrm{H}_{2} \mathrm{O}$ containing $1 \%$ TFA / $80 \% \mathrm{MeOH}$ containing $1 \%$ TFA at a flow rate of $10 \mathrm{~mL}$ $\mathrm{min}^{-1}$ over 60 min yielding leptoclinidamine B (13, $9.4 \mathrm{mg}$, $100.007 \%)$ and durabetaine A (7, $0.7 \mathrm{mg}, 0.005 \%)$ respectively. Fractions $38-40$ were combined and repurified by $\mathrm{C}_{18}$ HPLC with a gradient from $80 \% \mathrm{H}_{2} \mathrm{O}$ containing $1 \%$ TFA / $20 \% \mathrm{MeOH}$ containing $1 \%$ TFA to $20 \% \mathrm{H}_{2} \mathrm{O}$ containing $1 \%$ TFA / $80 \% \mathrm{MeOH}$

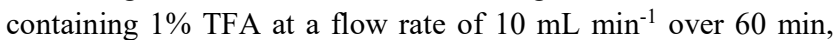
15 collecting $30 \mathrm{sec}$ fractions. Fractions eluting between $24 \mathrm{~min}$ and 32 min were combined and further purified by $\mathrm{C}_{18}$ HPLC with a gradient from $90 \% \mathrm{H}_{2} \mathrm{O}$ containing $1 \%$ TFA / $10 \% \mathrm{CH}_{3} \mathrm{CN}$ containing $1 \%$ TFA to $75 \% \mathrm{H}_{2} \mathrm{O}$ containing $1 \%$ TFA / $25 \%$ $\mathrm{CH}_{3} \mathrm{CN}$ containing $1 \%$ TFA at a flow rate of $10 \mathrm{~mL} \mathrm{~min}^{-1}$ over 60 $20 \mathrm{~min}$, collecting $30 \mathrm{sec}$ fractions yielding leptoclinidamine F (12, $0.4 \mathrm{mg}, 0.0003 \%$ ). Fractions $41-51$ for the first HPLC separation were combined and repurified by $\mathrm{C}_{18}$ HPLC with a gradient from $70 \% \mathrm{H}_{2} \mathrm{O}$ containing $1 \%$ TFA / 30\% MeOH containing $1 \%$ TFA to $30 \% \mathrm{H}_{2} \mathrm{O}$ containing $1 \%$ TFA / $70 \% \mathrm{MeOH}$ containing $1 \%$ TFA 25 at a flow rate of $10 \mathrm{~mL} \mathrm{~min}^{-1}$ over $60 \mathrm{~min}$, collecting $30 \mathrm{sec}$ fractions yielding leptoclinidamine $\mathrm{E}(\mathbf{1 1}, 0.3 \mathrm{mg}, 0.0002 \%)$, duramidine $\mathrm{C}(\mathbf{3}, 1.0 \mathrm{mg}, 0.0007 \%)$ and 6-bromo-1H-indolo-3-yloxoacetic acid methyl ester $(\mathbf{1 4}, 1.8 \mathrm{mg}, 0.001 \%)$. Fractions eluting between $18 \mathrm{~min}$ and $23 \mathrm{~min}$ were combined and further 30 purified by $\mathrm{C}_{18}$ HPLC with a gradient from $\mathrm{H}_{2} \mathrm{O}$ containing $1 \%$ TFA to $60 \% \mathrm{H}_{2} \mathrm{O}$ containing $1 \%$ TFA / $40 \% \mathrm{CH}_{3} \mathrm{CN}$ containing $1 \%$ TFA at a flow rate of $10 \mathrm{~mL} \mathrm{~min}^{-1}$ over $60 \mathrm{~min}$, collecting 30 $\mathrm{sec}$ fractions yielding duramidine A (1, $3.1 \mathrm{mg}, 0.002 \%)$, leptoclinidine A $\mathbf{5}, 5.2 \mathrm{mg}, 0.004 \%)$, leptoclinidamine C $(\mathbf{9}, 13.5$ $35 \mathrm{mg}, 0.009 \%)$, duramidine D (4, $1.1 \mathrm{mg}, 0.0008 \%)$, duramidine B (2, $5.3 \mathrm{mg}, 0.004 \%)$ and leptoclinidamine D (10, $1.2 \mathrm{mg}, 0.0008 \%)$ respectively. Fractions 52-60 from the first HPLC separation were combined and purified further by $\mathrm{C}_{18}$ HPLC with a gradient from $90 \% \mathrm{H}_{2} \mathrm{O}$ containing $1 \%$ TFA / $10 \% \mathrm{MeOH}$ containing $1 \%$ TFA 40 to $60 \% \mathrm{H}_{2} \mathrm{O}$ containing $1 \% \mathrm{TFA} / 40 \% \mathrm{MeOH}$ containing $1 \%$ TFA

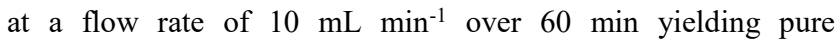
leptoclinidine B $(6,1.7 \mathrm{mg}, 0.001 \%)$ and durabetaine B (8, $1.3 \mathrm{mg}$, $0.0009 \%$ ).

45 Ascidian Sample 2 (G317469): The second freeze-dried and ground ascidian sample (10 g) was transferred to a conical flask (1 $\mathrm{L}) ; n$-hexane $(250 \mathrm{~mL})$ was added and the flask was shaken at 200 rpm for $2 \mathrm{~h}$. The $n$-hexane extract was filtered under gravity, and then discarded. $\mathrm{CH}_{2} \mathrm{Cl}_{2} / \mathrm{MeOH}(4: 1,250 \mathrm{~mL})$ were added to the de${ }_{50}$ fatted ascidian sample in the conical flask and shaken at $200 \mathrm{rpm}$ for $2 \mathrm{~h}$. The resulting extract was filtered under gravity, and set aside. $\mathrm{MeOH}(250 \mathrm{~mL})$ was added to the ascidian sample, and the flask shaken at $200 \mathrm{rpm}$ for $2 \mathrm{~h}$ before filtration. Another volume of $\mathrm{MeOH}(250 \mathrm{~mL})$ was then added and the $\mathrm{MeOH} /$ ascidian 55 mixture shaken for a further $16 \mathrm{~h}$ at $200 \mathrm{rpm}$, followed by gravity filtration. All $\mathrm{CH}_{2} \mathrm{Cl}_{2} / \mathrm{MeOH}$ extracts were combined and dried under reduced pressure to yield a dark brown gum $(1 \mathrm{~g})$. This extract was resuspended in $\mathrm{CH}_{2} \mathrm{Cl}_{2} / \mathrm{MeOH}$ and adsorbed to $\mathrm{C}_{18}$ silica then packed into a stainless steel refillable HPLC column (10 ${ }_{60} \times 30 \mathrm{~mm}$ ) that was connected to a semi-preparative $\mathrm{C}_{18}$ Betasil HPLC column. Isocratic conditions of $10 \% \mathrm{MeOH}(0.1 \%$ TFA $) / 90 \% \mathrm{H}_{2} \mathrm{O}(0.1 \%$ TFA) were initially performed for the first $10 \mathrm{~min}$, followed by a linear gradient to $\mathrm{MeOH}(0.1 \%$ TFA $)$ in 40 min, then isocratic conditions of $\mathrm{MeOH}(0.1 \%$ TFA) were 65 maintained for a further $10 \mathrm{~min}$, all at a flow rate of $9 \mathrm{~mL} \mathrm{~min}{ }^{-1}$. Sixty fractions $(60 \times 1 \mathrm{~min})$ were collected from time $=0 \mathrm{~min}$, and analysed by $( \pm)$-LRESIMS. Fractions 33, 34 and 36 contained the ions of interest and were further purified by semi-preparative HPLC using a $\mathrm{C}_{18}$ Luna column. Separation of both fractions 33 70 and 34 involved isocratic conditions of $5 \% \mathrm{MeOH}(0.1 \% \mathrm{TFA}) /$ $95 \% \mathrm{H}_{2} \mathrm{O}(0.1 \% \mathrm{TFA})$ for $10 \mathrm{~min}$, followed by a linear gradient to $60 \% \mathrm{MeOH}\left(0.1 \%\right.$ TFA) $/ 40 \% \mathrm{H}_{2} \mathrm{O}(0.1 \% \mathrm{TFA})$ in $10 \mathrm{~min}$, and then another linear gradient to $90 \% \mathrm{MeOH}(0.1 \%$ TFA $) / 10 \% \mathrm{H}_{2} \mathrm{O}$ $(0.1 \%$ TFA) for $30 \mathrm{~min}$, followed by $\mathrm{MeOH}(0.1 \%$ TFA) for 10 $75 \mathrm{~min}$, all at a flow rate of $4 \mathrm{~mL} \mathrm{~min}^{-1}$. Sixty fractions $(60 \times 1 \mathrm{~min})$ were collected from time $=0 \mathrm{~min}$, and analysed by $( \pm)$-LRESIMS . From fraction 34, fractions $36(\mathrm{~m} / \mathrm{z} 462 / 464 / 466)$ and $42(\mathrm{~m} / \mathrm{z} 507)$ contained the ions of interest and following lyophilisation yielded compound 11 (0.77 mg, 0.008\%) and 3 (0.67 mg, 0.007\%) 80 respectively. Fraction 33 yielded fractions 43 and 44 that were combined and purified using the same conditions described above to yield compound $4(0.35 \mathrm{mg}, 0.004 \%)$. Fraction 36 obtained from the first isolation step was purified at a flow rate of $4 \mathrm{~mL} \mathrm{~min}{ }^{-1}$ using a linear gradient starting at $10 \% \mathrm{MeOH}(0.1 \%$ TFA) $/ 90 \%$ ${ }_{85} \mathrm{H}_{2} \mathrm{O}(0.1 \%$ TFA $)$ and finishing at $50 \% \mathrm{MeOH}(0.1 \%$ TFA $) / 50 \%$ $\mathrm{H}_{2} \mathrm{O}(0.1 \%$ TFA $)$ in $5 \mathrm{~min}$. This was followed by a linear gradient to $80 \% \mathrm{MeOH}\left(0.1 \%\right.$ TFA) $/ 20 \% \mathrm{H}_{2} \mathrm{O}(0.1 \%$ TFA $)$ in $30 \mathrm{~min}$, and then a gradient to $\mathrm{MeOH}(0.1 \% \mathrm{TFA})$ in $10 \mathrm{~min}$, which was held at these conditions for a further $5 \mathrm{~min}$. This afforded the known 90 compound leptoclinidamine C $(\mathbf{9}, 1.3 \mathrm{mg}, 0.013 \%)$, which eluted at 43-44 min.

Duramidine A (1) yellow gum; $[\alpha] \mathrm{D}^{23}+74(c 0.025, \mathrm{MeOH})$; UV $\lambda_{\max }(\mathrm{MeOH}) / \mathrm{nm}(\log \varepsilon) 216$ (4.56), 285 (3.69), 320 (3.49); IR ${ }_{95} \mathrm{U}_{\max }(\mathrm{film}) / \mathrm{cm}^{-1} 3190,1720,1700,1683,1653,1544,1457 ;{ }^{1} \mathrm{H}$ and ${ }^{13} \mathrm{C}$ NMR data (DMSO- $d_{6}$ ) see Tables 1 and 2; (+)-LRESIMS $m / z$ $545\left(\mathrm{MNa}^{+} 15 \%\right), 523\left(\mathrm{MH}^{+} 90 \%\right), 443\left(\mathrm{MH}^{+}-\mathrm{SO}_{3} 10 \%\right), 515\left(\mathrm{M}^{+}\right.$ $30 \%$ ); (+)-HRESIMS $\mathrm{m} / z 523.1133$ (calcd for $\mathrm{C}_{21} \mathrm{H}_{23} \mathrm{~N}_{4} \mathrm{O}_{10} \mathrm{~S}$, $523.1135)$.

100

Duramidine B (2) yellow gum; $[\alpha]_{\mathrm{D}}^{23}+94(c$ 0.05, MeOH); UV $\lambda_{\max }(\mathrm{MeOH}) / \mathrm{nm}(\log \varepsilon) 214$ (4.52), 284 (3.65), 318 (3.48); IR Umax $($ film $) / \mathrm{cm}^{-1} 1721,1698,1682,1651,1561,1456 ;{ }^{1} \mathrm{H}$ and ${ }^{13} \mathrm{C}$ NMR data (DMSO- $d_{6}$ ) see Tables 1 and 2; (+)-LRESIMS $m / z 443$ $105\left(\mathrm{MH}^{+} 100 \%\right)$; (+)-HRESIMS $m / z 443.1583$ (calcd for $\mathrm{C}_{21} \mathrm{H}_{23} \mathrm{~N}_{4} \mathrm{O}_{7}$, 443.1567).

Duramidine C (3) yellow gum; $[\alpha]_{\mathrm{D}}+93(c 0.044, \mathrm{MeOH})$; UV $\lambda_{\max }(\mathrm{MeOH}) / \mathrm{nm}(\log \varepsilon) 233$ (4.12), 250sh (3.98), $316(4.24) ;{ }^{1} \mathrm{H}$ 110 NMR data and ${ }^{13} \mathrm{C}$ NMR data (DMSO- $d_{6}$ ) see Tables 1 and 2; (-)-

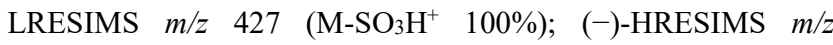
507.0808 (calcd for $\mathrm{C}_{20} \mathrm{H}_{19} \mathrm{~N}_{4} \mathrm{O}_{10} \mathrm{~S}, 507.0827$ ).

Duramidine D (4) yellow gum; $[\alpha]_{D^{23}}+7(c 0.023, \mathrm{MeOH})$; UV ${ }_{115} \lambda_{\max }(\mathrm{MeOH}) / \mathrm{nm}(\log \varepsilon) 230$ (3.77), 249sh (3.65), $313(3.75) ;{ }^{1} \mathrm{H}$ and ${ }^{13} \mathrm{C}$ NMR data (DMSO- $d_{6}$ ) see Tables 1 and 2; (-)-LRESIMS 
$m / z 427$ (M-H ${ }^{+}$100\%); (-)-HRESIMS m/z 427.1244 (calcd for $\left.\mathrm{C}_{20} \mathrm{H}_{19} \mathrm{~N}_{4} \mathrm{O}_{7}, 427.1244\right)$.

Leptoclinidine A (5) yellow gum; $[\alpha]_{\mathrm{D}}^{24}-29$ ( $c$ 0.26, MeOH); ${ }_{5} \mathrm{UV} \lambda_{\max }(\mathrm{MeOH}) / \mathrm{nm}(\log \varepsilon) 216$ (4.55), 252 (4.08), 282 (3.49); IR $U_{\max }($ film $) / \mathrm{cm}^{-1} 1720,1700,1683,1653 ;{ }^{1} \mathrm{H}$ and ${ }^{13} \mathrm{C}$ NMR data (DMSO- $\left.d_{6}\right)$ see Table 3; (+)-LRESI MS $m / z 504\left(\mathrm{MNa}^{+} 50 \%\right)$, $502\left(\mathrm{MNa}^{+}\right.$50\%); (+)-HRESIMS $\mathrm{m} / z \quad 502.0224$ (calcd for $\left.\mathrm{C}_{19} \mathrm{H}_{18}{ }^{79} \mathrm{BrN}_{3} \mathrm{O}_{7} \mathrm{Na}, 502.0226\right)$.

10

Leptoclinidine B (6) colourless gum; $[\alpha]_{\mathrm{D}^{24}}-4.6$ (c 0.3 , $\mathrm{MeOH}) ; \mathrm{UV} \lambda_{\max }(\mathrm{MeOH}) / \mathrm{nm}(\log \varepsilon) 216$ (5.18), 252 (4.86), 306 (4.81); IR $U_{\max }(\mathrm{film}) / \mathrm{cm}^{-1} 2946,1718,1698,1682,1674,1456$, 1204; ${ }^{1} \mathrm{H}$ and ${ }^{13} \mathrm{C}$ NMR data (DMSO- $d_{6}$ ) see Table 3; (+)-LRESI $15 \mathrm{MS} m / z 680\left(\mathrm{MNa}^{+} 50 \%\right), 678\left(\mathrm{MNa}^{+} 50 \%\right) ;(+)$-HRESIMS $m / z$ 678.0669 (calcd for $\mathrm{C}_{29} \mathrm{H}_{26}{ }^{79} \mathrm{BrN}_{3} \mathrm{O}_{10} \mathrm{Na}, 678.0699$ ).

Durabetaine A (7) colourless gum; $[\alpha]_{\mathrm{D}}^{23}-64(c 0.02, \mathrm{MeOH})$; UV $\lambda_{\max }(\mathrm{MeOH}) / \mathrm{nm}(\log \varepsilon) 216$ (4.38), 302 (3.71); IR U max 20 (film) $/ \mathrm{cm}^{-1} 2919,2849,1735,1686,1651,1542 ;{ }^{1} \mathrm{H}$ and ${ }^{13} \mathrm{C}$ NMR data (DMSO- $d_{6}$ ) see Table 4; (+)-LRESIMS $m / z 428\left(\mathrm{M}^{+} 100 \%\right)$; (+)-HRESIMS $m / z 428.1918$ (calcd for $\mathrm{C}_{20} \mathrm{H}_{30} \mathrm{NO}_{9}, 428.1921$ ).

Durabetaine B (8) colourless gum; $[\alpha]_{\mathrm{D}}{ }^{24}-77$ (c 0.008 , $\left.{ }_{25} \mathrm{MeOH}\right)$; IR $U_{\max }(\mathrm{film}) / \mathrm{cm}^{-1} 2972,1733,1701,1681 ;{ }^{1} \mathrm{H}$ and ${ }^{13} \mathrm{C}$ NMR data (DMSO- $\left.d_{6}\right)$ see Table 4; (+)-LRESIMS $m / z 475\left(\mathrm{M}^{+}\right.$ 50\%), $473\left(\mathrm{M}^{+}\right.$50\%); (+)-HRESIMS $\mathrm{m} / z 473.0908$ (calcd for $\left.\mathrm{C}_{19} \mathrm{H}_{26}{ }^{79} \mathrm{BrN}_{2} \mathrm{O}_{7}, 473.0923\right)$.

30 Leptoclinidamine D (10) colourless gum; $[\alpha] \mathrm{D}^{23}-18(c$ 0.04, $\mathrm{MeOH}) ; \mathrm{UV} \lambda_{\max }(\mathrm{MeOH}) / \mathrm{nm}(\log \varepsilon) 216$ (4.34), 286 (3.65); IR $U_{\max }\left(\right.$ film) $/ \mathrm{cm}^{-1} 1701,1686,1653 ;{ }^{1} \mathrm{H}$ and ${ }^{13} \mathrm{C}$ NMR data (DMSOd6) see Table 5; (+)-LRESIMS m/z $467\left(\mathrm{M}^{+}\right.$50\%), $465\left(\mathrm{M}^{+}\right.$50\%); $(+)$-HRESIMS $\mathrm{m} / \mathrm{z} 465.0571$ (calcd for $\mathrm{C}_{19} \mathrm{H}_{22}{ }^{79} \mathrm{BrN}_{4} \mathrm{O}_{3} \mathrm{~S}$, ${ }_{35}$ 465.0596).

Leptoclinidiamine E (11) yellow gum; UV $\lambda_{\max }(\mathrm{MeOH}) / \mathrm{nm}$ ( $\log \varepsilon) 224$ (4.24), 286 (3.30); IR $U_{\max }\left(\right.$ film) $/ \mathrm{cm}^{-1}$ 3430, 2952, 1684, $1653 ;{ }^{1} \mathrm{H}$ and ${ }^{13} \mathrm{C}$ NMR data (DMSO- $d_{6}$ ) see Table 6; (+)${ }_{40}$ LRESIMS $m / z 462\left(\mathrm{M}^{+}\right.$50\%), $464\left(\mathrm{M}^{+} 100 \%\right), 466\left(\mathrm{M}^{+}\right.$50\%); (+)-HRESIMS $m / z \quad 461.9484$ (calcd for $\mathrm{C}_{15} \mathrm{H}_{18}{ }^{79} \mathrm{Br}_{2} \mathrm{~N}_{3} \mathrm{O}_{2} \mathrm{~S}$, 461.9481).

Leptoclinidamine F (12) yellow gum; UV $\lambda_{\max }(\mathrm{MeOH}) / \mathrm{nm}$ 45 ( $\log \varepsilon) 218$ (4.41), 284 (3.26); IR U $\max \left(\right.$ film) $/ \mathrm{cm}^{-1}$ 3421, 2923, 1701,$1651 ;{ }^{1} \mathrm{H}$ and ${ }^{13} \mathrm{C}$ NMR data (DMSO-d6) see Table 1; (+)LRESIMS $m / z 386\left(\mathrm{M}^{+}\right.$50\%), 384; (+)-HRESIMS m/z 384.039 (calcd for $\mathrm{C}_{15} \mathrm{H}_{19}{ }^{79} \mathrm{BrN}_{3} \mathrm{O}_{2} \mathrm{~S}, 384.0381$ ).

\section{${ }_{50}$ Anti-microbial assay}

Antibacterial activity was determined using cellular bioassays, and quantified by the spectroscopic analysis of the metabolic dye, Resazurin. The bioassays were conducted in $500 \mu \mathrm{L}$, 96 well microtiter plates, with each well containing broth $(75 \mu \mathrm{L})$, 55 microbial inoculate stock solution $(37.5 \mu \mathrm{L})$, and Milli-Q $\mathrm{H}_{2} \mathrm{O}$ (32.5 $\mu \mathrm{L})$. Finally DMSO $(5 \mu \mathrm{L})$ stocks of the pure compounds (114), or positive controls (Piperacillin for P. aeruginosa MIC
$2 \mu \mathrm{g} / \mathrm{mL}$ and $S$. aureus MIC $0.13 \mu \mathrm{g} / \mathrm{mL}$ ), were transferred to the wells in triplicate and incubated for $18 \mathrm{~h}$. Microbial inoculate stock 60 solutions of Pseudomonus aeruginosa and Staphylococcus aureus were prepared by transferring a single colony from a plate to a sterile falcon tube, containing $1 \mathrm{~mL}$ of single strength Luria bertani broth (prepared by dissolving $25 \mathrm{~g}$ of powdered broth in $1 \mathrm{~L}$ of distilled $\mathrm{H}_{2} \mathrm{O}$ and sterilised by autoclaving for $20 \mathrm{~min}$ at $121^{\circ} \mathrm{C}$ ).

${ }_{65}$ The stock solution was incubated for $18 \mathrm{~h}$, at $37{ }^{\circ} \mathrm{C}$ while being shaken at $100 \mathrm{rpm}$. After the incubation, $40 \mu \mathrm{L}$ was transferred to a new sterile falcon tube and adjusted to $2 \mathrm{~mL}$, with single strength broth. $100 \mu \mathrm{L}$ of this solution was then transferred to a $15 \mathrm{~mL}$ sterile tube and adjusted to $10 \mathrm{~mL}$ with single strength broth. A 70 resazurin stock solution was prepared by dissolving powdered resazurin $(16.14 \mathrm{mg})$ in sterilised water $(100 \mathrm{~mL})$. After the microbial solutions were incubated with the tests or control solutions for $18 \mathrm{~h}$ resazurin stock solution $(20 \mu \mathrm{L})$ was added to all wells, and incubated for a further $1 \mathrm{~h}$ at $37^{\circ} \mathrm{C}$ while being shaken 75 at $100 \mathrm{rpm}$. Inhibition was quantified by determining the percentage inhibition of test compounds in comparison with positive and solvent controls using a Fluoroskan Ascent fluorospectrometer (excitation wavelength $570 \mathrm{~nm}$ and emission wavelength $620 \mathrm{~nm})$.

\section{${ }_{80}$ Cytotoxicity assay}

All compounds were tested against the prostate cancer cell line LNCaP and the breast cancer cell line MDA-MB-231 using a real time cell analyser (xCELLigence, Roche Applied Systems). LNCaP and MDA-MB-231 cells were routinely grown in RPMI or 85 DMEM medium, respectively, supplemented with 10\% (v/v) FBS (Invitrogen, USA) at $37^{\circ} \mathrm{C}$ in the presence of $5 \% \mathrm{CO}_{2}$. These cells were seeded in a 96-well E-plate ${ }^{\mathrm{TM}}$ at a density of $10 \times 10^{3}$ cells $(\mathrm{LNCaP})$ or $5 \times 10^{3}$ cells (MDA-MB-231) in a final volume of 150 $\mu \mathrm{L}$. The attachment of the cells was monitored for $4 \mathrm{~h}$ every $2 \mathrm{~min}$. ${ }_{90}$ After this period, the conditions of the cells were analysed every 1 h. After $24 \mathrm{~h}$, the cells were treated with compounds 1-14 at a final concentration of $10 \mu \mathrm{M}$. The biological status of the cells were monitored for $2 \mathrm{~h}$ every minute and then for $70 \mathrm{~h}$ every hour. Doxorubicin $(5 \mu \mathrm{M})$ and DMSO $(0.1 \%)$ were used as controls.

\section{${ }_{95}$ Acknowledgements}

We thank H. T. Vu (Griffith University) for acquiring the HRESIMS measurements. We would also like to thank J. N. A. Hooper and P. Mather (Queensland Museum) for ascidian collection and taxonomic identification, respectively. M. S. L. is 100 grateful for a PhD scholarship provided by the Eskitis Institute and Griffith University. We thank J. Hayton and G. Grant (Griffith University) for antimicrobial testing.

\section{Notes and references}

${ }^{a}$ Environmental Futures Centre, Griffith University, Gold Coast, QLD 105 4222, Australia. Fax: +61 7 55529047; Tel: +61 7 55529187; Email: a.carroll@griffith.edu.au

${ }^{b}$ Eskitis Institute, Griffith University, Brisbane, QLD 4111, Australia

$\dagger$ Both authors contributed equally to this work.

\$ Electronic Supplementary Information (ESI) available: 1D and 2D NMR 110 spectra for duramidines A-D, leptoclinidines A and B, durabetaines A and B and leptoclinidamines D-F. See DOI: 10.1039/b000000x/ 
1 A. R. Carroll and V. M. Avery, J. Nat. Prod., 2009, 72, 696-699.

2 M. Liberio, D. Sooraj, E. D. Williams, Y. J. Feng and R. A. Davis, Tetrahedron Lett., 2011, 52, 6729-6731.

53 B. Bao, P. Zhang, Y. Lee, J Hong, C.-O. Lee and J. H. Jung, Mar. Drugs, 2007, 5, 31-39.

4 L. A. McDonald, J. C. Swersey, C. M. Ireland, A. R Carroll, J. C. Coll, B. F. Bowden, C. R. Fairchild and L. Cornell, Tetrahedron. 1995, 51, 5237-5244.

105 E. Pretsch, P. Buhlmann and C. Affolter, Structure Determination of Organic Compounds: Tables of Spectral Data Springer-Verlag: Berlin Heidelberg, 2000.

6 I. A. Zuleta, M. L. Vitelli, R. Baggio, M. T. Garland, A. M. Seldes and J. A. Palermo, Tetrahedron, 2002, 58, 4481-4486.

157 G. H. Schmid, Can. J. Chem., 1968, 46, 3415-3418.

8 R. P. Collins and K. Kalnins, J. Insect Physiol., 1970, 16, 1587-1589.

9 S.Inoue, K.Okada, H.Tanino, H. Kakoi, Y. Ohnishi, and N. Horii, Chem. Lett., 1991, 4, 563-564.

10 A. Guerriero, M. D'Ambrosio, F. Pietra, C. Debitus and O. Ribes, $J$. Nat. Prod., 1993, 56, 1962-1970.

11 S. Tsukamoto, H. Hirota, H. Kato and N. Fusetani, Tetrahedron Lett., 1993, 34, 4819-4822.

12 R. M. Van Wagoner, J. Jompa, A. Tahir and C. M. Ireland, J. Nat. Prod., 2001, 64, 1100-1101.

2513 A. Aiello, E. Fattorusso, S. Magno, G. Misuraca, and E. Novellino, Experientia, 1987. 43, 950-952.

14 V. Gotor and F. Moris, Synthesis, 1992, 7, 626-628.

15 M. Kato, K. Adachi, K. Hajiro-Nakanishi, E. Ishigaki, H. Sano and S. Miyachi, Phytochemistry, 1994, 37, 279-280.

3016 M. Kato, M. Sakai, K. Adachi, H. Ikemoto and H. Sano, Phytochemistry, 1996, 42, 1341-1345.

17 K. Kunzler and W. Eichenberger, Phytochemistry, 1997, 46, 883-892.

18 C. J. Smith, R. L. Hettich, J. Jompa, A.Tahir, M. V. Buchanan, C. M. Ireland, J. Org. Chem., 1998, 63, 4147-4150.

35 